\title{
Identification and taxonomy of the West Palaearctic species of Tachina Meigen (Diptera: Tachinidae) based on male terminalia and molecular analyses
}

\author{
Hana Novotná, Jaromír Vaňhara*, Andrea Tóthová, Natália Muráriková, \\ Petr Bejdák, Michal Tkoč \& Rudolf Rozkošný
}

\begin{abstract}
Novotná, H., Vaňhara, J., Tóthová, A., Muráriková, N., Bejdák, P., Tkoč, M. \& Rozkošný, R. 2009: Identification and taxonomy of the West Palaearctic species of Tachina Meigen (Diptera: Tachinidae) based on male terminalia and molecular analyses. - Entomol. Fennica 20: 139-169.

The male postabdominal structures of the West Palaearctic species of the genus Tachina are described. A new identification key is given. Characters are illustrated by original pen drawings and deep focus micrographs, some of them for the first time. The results are documented by molecular analyses (based on $\mathrm{CO}^{\circ} \mathrm{I}$, $\mathrm{Cyt}^{\circ} \mathrm{b}, 12 \mathrm{~S}$, and 16S rDNA). This approach solves old taxonomical discrepancies, which resulted in these conclusions: 1) the taxonomic concept of the genus was evaluated; 2) the position of the present subgenus Tachina s.str. seems to be untenable: T. grossa (Linnaeus, 1758) could be categorized inside existing subgenus Tachina s.str. and a new subgenus could be created for T. magna (GiglioTos, 1890); 3) an expected new species from subgenus Eudoromyia was confirmed; 4) T. nigrohirta (Stein, 1924) having been resurrected from synonymy was confirmed as a valid species; 5) some differences between central European and Japanese specimens of T. nupta (Rondani, 1859) were found.
\end{abstract}

H. Novotná, J. Vaňhara, A. Tóthová, N. Muráriková, P. Bejdák, M. Tkoč \& R. Rozkošný, Masaryk University, Faculty of Science, Department of Botany and Zoology, Kotlářská 2, $611^{\circ} 37$ Brno, Czech Republic; *Corresponding author's e-mail:vanhara@sci.muni.cz

Received 17 October 2008, accepted 18 May 2009

\section{Introduction}

Species of the genus Tachina occur in the Neotropical, Nearctic, Palaearctic, and Oriental Regions but they are apparently missing in the Afrotropical and Australasian Regions (O'Hara 2006). There is no known species with a Holarctic distribution (O'Hara \& Wood 2004). The recent concept of the genus embraces 42 species in the Palaearctic Region (Herting 1984, Herting \& Dely-Draskovits 1993). The East Palaearctic fauna appears to be richer than the West Palaearctic. The recorded number of species described from the former USSR and present China (Zimin \& Kolomietz 1984, Chao et al. 1998, O'Hara et al. 2009) comprises 44 and 51 taxa respectively, though both lists include a number of vague synonyms. The West Palaearctic fauna is much more limited; the Fauna Europaea database includes 12 known species only (Tschorsnig et al. 2004). The knowledge of Tachina taxonomy and phylogenetic relationships of its species is still insufficient. 
Table 1. Male postabdomen examined (for the DNA analyses see also Table 2). Abbreviations for countries: ATAustria, CZ-Czech Rep., DE-Germany, ES-Spain, FI-Finland, FR-France, GR-Greece, IT-Italy, RU-European Russia, SE-Sweden, SK-Slovakia. For abbreviations of collectors see Material and methods. "*": other specimens for DNA validation without postabdominal analysis.

\begin{tabular}{|c|c|c|c|}
\hline Taxon & Provenance & Males/DNA validation & Collection \\
\hline \multicolumn{4}{|l|}{ Tachina } \\
\hline \multicolumn{4}{|l|}{ (Eudoromyia) } \\
\hline canariensis & ES-Canary Isls & $2 / 1$ & TSCH, ZIE \\
\hline casta & ES, IT, Serbia & $4 / 3$ & CER, TSCH, VAŇ, ZIE \\
\hline corsicana & GR, Tunisia & $2 / 2$ & CER, ZIE \\
\hline fera & AT, CZ, FI, IT, SE, SK & $20 / 2$ & BER, CER, VAÑ \\
\hline magnicornis & $\mathrm{CZ}, \mathrm{FI}, \mathrm{IT}, \mathrm{SE}, \mathrm{SK}$ & $13 / 2$ & BAR, BER, TSCH, VAŇ \\
\hline nupta & CZ, Iran, IT, Japan & $7 / 4$ & CER, ICH, VAŇ \\
\hline $\begin{array}{l}\text { sp. } \\
\text { (Tachina) }\end{array}$ & FI, FR, SE, SK & $12 / 5$ & BER, ČEP, TSCH, VAŇ, ZIE \\
\hline $\begin{array}{l}\text { magna } \\
\text { (Servillia) }\end{array}$ & ES, GR, IT & $3 / 2$ & CER, TSCH, VAŇ \\
\hline lurida & CZ, Morocco & $7 / 2$ & BAR, VAŇ \\
\hline nigrohirta & $\mathrm{DE}, \mathrm{SK}$ & $4 / 2$ & ČEP, TSCH, VAŇ \\
\hline $\begin{array}{l}\text { ursina } \\
\text { (Tachina) }\end{array}$ & $\mathrm{CZ}, \mathrm{IT}, \mathrm{RU}, \mathrm{SK}$ & $6 / 1$ & BAR, CER, TSCH, VAŇ \\
\hline $\begin{array}{l}\text { grossa } \\
\text { (Echinogaster) }\end{array}$ & CZ, SK & $2 / 1$ & TSCH, VAŇ \\
\hline praeceps & Kirgizia & $2 / 2^{*}$ & VAŇ \\
\hline \multicolumn{4}{|l|}{ Outgroups } \\
\hline \multicolumn{4}{|l|}{ Tachinidae } \\
\hline Germaria ruficeps & $\mathrm{CZ}, \mathrm{SK}$ & $2 / 1^{*}$ & ČEP, VAŇ \\
\hline Gonia divisa & SK & $1 /-$ & ČEP \\
\hline Gymnocheta viridis & $C Z$ & $1 / 1^{*}$ & ČEP \\
\hline Linnaemya picta & SK & $3 / 1^{*}$ & ČEP \\
\hline Nemoraea pellucida & SK & $1 /-$ & ČEP \\
\hline Nowickia ferox & $\mathrm{CZ}$ & $1 / 1^{*}$ & BAR \\
\hline Peleteria rubescens & SK & $1 /-$ & ČEP \\
\hline Phasia hemiptera & $\mathrm{CZ}$ & $1 /-$ & ČEP \\
\hline Schineria tergestina & SK & $1 /-$ & ČEP \\
\hline Winthemia variegata & SK & $1 /-$ & ČEP \\
\hline Rhinophoridae & & & \\
\hline Stevenia atramentaria & $\mathrm{CZ}$ & $1 /-$ & BAR \\
\hline
\end{tabular}

The hitherto available keys are often based on extensively variable structures and/or colour characters, while the male and female terminalia are only rarely considered. Moreover, some present keys have demonstrated a distinct species overlapping for some of the frequently used key characteristics, see e.g. morphometry of fore claws and tarsi, female frons of T. magnicornis and $T$. fera, etc. in the identification key in Tschorsnig \& Herting (1994). The large number of synonymic names found in each regional fauna could therefore be regarded, at least partly, as a consequence of this situation. Thus, the West Palaearctic fauna
(Herting \& Dely-Draskovits 1993, Tschorsnig et al. 2004) comprises besides 12 valid species also 45 available synonymic names. The present concept of species taxonomy and higher taxa of the genus Tachina was published by Herting (1984) in his Catalogue where he recognized four subgenera.

The significance of the specific differences found in structures constituting the male terminalia in Diptera is generally accepted (cf. McAlpine 1981, 1989). The first extensive modern and significant study concerning the male postabdomen, with emphasis on the phallus and gonites of 240 
species, was published by Verbeke $(1962,1963)$. Four selected European species of the genus Tachina were studied in detail. Verbeke's interpretation of specific structures corresponds with the generally accepted epandrial hypothesis (Mcalpine 1981, Sinclair 2000). A subsequent important and extensive study was published by Tschorsnig (1985). He discussed evolutionary trends in characters currently used in identification keys to Tachinidae and stressed a necessary revision of all the generally used characters. Altogether 423 species were studied and selected characters were compared for 32 species groups. The author's attention was chiefly focused on the groups not treated by Verbeke (1962). A key to tribes was also proposed as a result of Tschorsnig's comparative studies. Of the genus Tachina, T. fera, T. grossa and T. ursina were examined. Wood (1987) and Tschorsnig \& Richter (1998) presented some structures of the male terminalia at the family level as a part of the Manual of Nearctic Diptera and that of the Palaearctic Diptera, respectively. Pape (1992) examined several characters of the male terminalia in his phylogenetic study concerning the Tachinidae family group. Also Tschorsnig \& Herting (1994) in their key to Central European species used some characters of the male postabdomen although to a lesser extent.

DNA analyses were used rather sporadically for the family Tachinidae during the last decade. Vossbrinck \& Friedman (1989) used primarily DNA sequences for tachinid phylogeny and did not support a monophyletic status of Tachinidae within Cyclorrhapha. Concerning rapid successive evolutionary separations, it was also suggested that those relationships cannot be differentiated using gene sequences of $28 \mathrm{~S}$ rDNA. Nirmala et al. (2001) used Nemoraea pellucida as an example for Tachinidae for analysis of Calyptratae. On the basis of $16 \mathrm{~S}$ and $18 \mathrm{~S}$ rDNA they did not find differentiated relationships for families close to the Tachinidae. The largest phylogenetic studies of the family Tachinidae were published by Stireman $(2002,2005)$. He used 55 species of the subfamily Exoristinae and 2 nuclear genes (28S rDNA and EF-1 $\alpha$ ). Different types of analyses brought extensive but in many cases contradictory results. Monophyly of the family Tachinidae and subfamily Exoristinae was supported, but some genera from Exoristinae appear divergent. The monophyly of subfamilies Tachininae and Phasinae was doubted. Besides phylogeny in Tachinidae, DNA-markers to the species identification (barcoding) were also used. Augustí et al. (2005) offered species specific primers for Lydella thompsoni and Pseudoperichaeta nigrolineata, which helped them to find parasitoid larvae in caterpillars of Ostrinia nubilalis (Lepidoptera, Crambidae), a pest of corn. Smith et al. (2006) studied an ability of specific sequences of DNA barcodes (CO I, ITS 1) to differentiate cryptic species and their context with their host specializations (Smith et al. 2007). Gariepy et al. (2007) summarized the PCR methods used in parasites and predators, and introduced Tachinidae as a suitable model group.

\section{Material and methods}

The nomenclature and systematic position of the West Palaearctic Tachina species follow Herting \& Dely-Draskovits (1993) and in several cases also Herting (1984). Terminology of dipteran male terminalia was adopted from Sinclair (2000) but some of the terms used for specific structures by Tschorsnig (1985) are also applied. Two terms are introduced as new: callus of syncercus and spine of syncercus.

The material was identified by C. Bergström, P. Cerretti, J. Čepelák, B. Herting, L. P. Mesnil, H. Novotná, R. Rozkošný, H.-P. Tschorsnig, J. Vaňhara, and J. Ziegler.

The following collections were studied:

BAR - Miroslav Barták, Czech University of Agriculture, Faculty of Agrobiology, Food and Natural Resources, Department of Zoology and Fishery, 16521 Praha 6-Suchdol, Czech Republic; bartak@af.czu.cz

BER - Christer Bergström, Säves väg 10, Uppsala, SE-75263, Sweden; christer.bergstrom@zeta.telenordia.se

ČEP- Juraj Čepelák (late), coll. deposited partly with Jaromír Vaňhara (corresponding author)

CER - Pierfilippo Cerretti, Università degli Studi di Roma "La Sapienza", Dipartimento di Biologia Animale e dell'Uomo, Viale dell'Università 32,00185 Roma, Italy; pierfilippocerretti@yahoo.it 
Table 2. Material under DNA analysis and GenBank accession numbers (for abbreviations used see Table 1 and Material and methods).

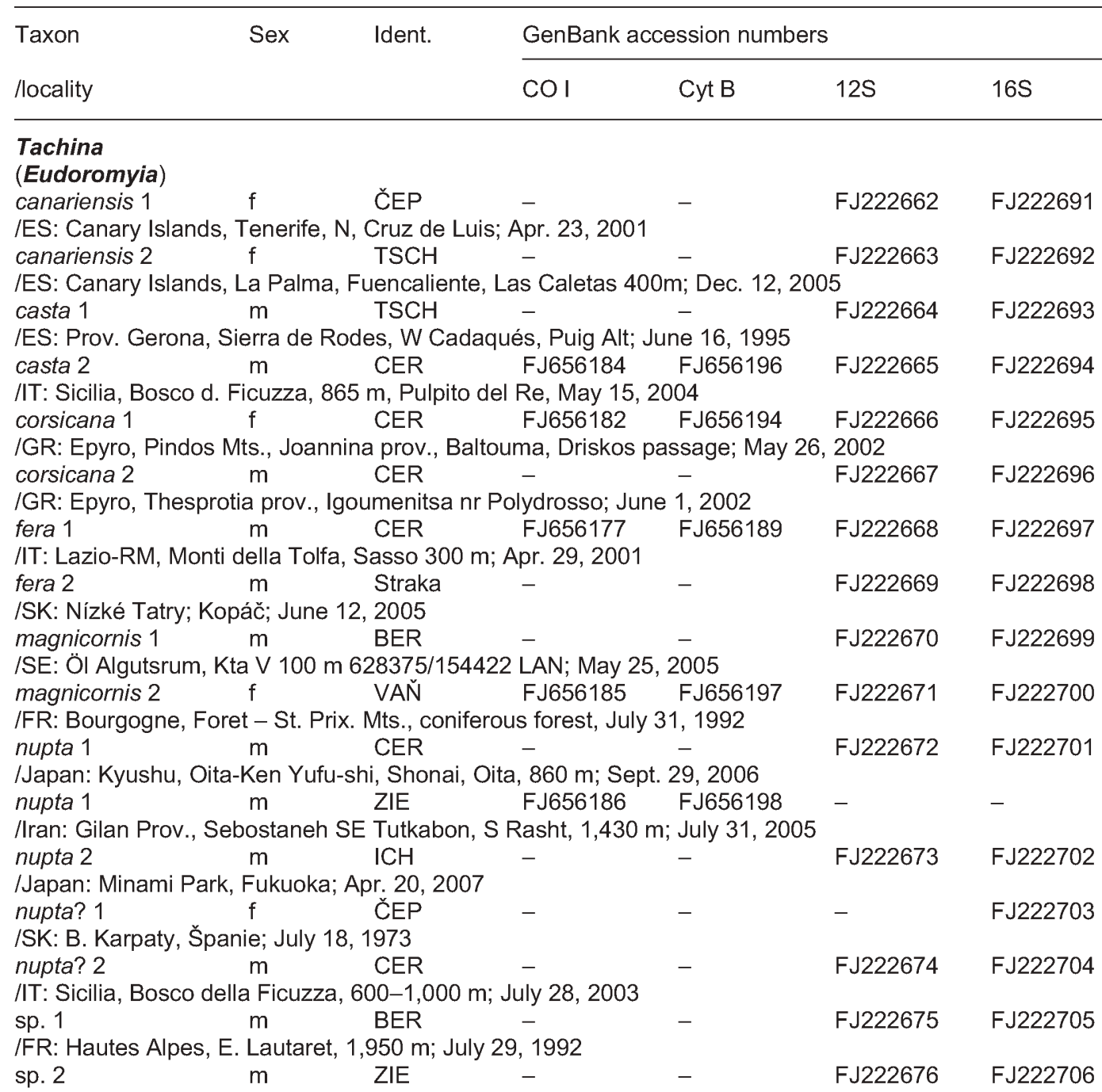

/FR: Dauphine Prov. H. Alpes, Vallee de la Guisane, E Col du Lautaret 1,950 m; July 29, 1992

(Tachina)

magna 1

magna 2 CER FJ656183

/GR: Thessalia, Trikala prov., Vlahava, 650 m; Apr. 29, 2003

$\begin{array}{lll}- & \text { FJ222677 } & \text { FJ222707 } \\ \text { FJ656195 } & \text { FJ222678 } & \text { FJ222708 }\end{array}$

(Servillia)

$\begin{array}{lllllll}\text { lurida } 1 & f & \text { ČEP } & \text { FJ656178 } & \text { FJ656190 } & \text { FJ222679 } & \text { FJ222709 }\end{array}$

/SK: Biele Karpaty, Španie; Apr. 25, 1993

lurida $2 \quad \mathrm{~m}$ Novotna

/CZ: Brno, Hády Hill; Apr. 23, 2007

ursina 1 f Mückst.

FJ222680 FJ222710

/CZ: Žd'árské vrchy; March 31, 2005 


\begin{tabular}{|c|c|c|c|c|c|}
\hline \multirow{2}{*}{$\begin{array}{l}\text { Taxon } \\
\text { /locality }\end{array}$} & \multirow[t]{2}{*}{ Ident. } & \multicolumn{4}{|c|}{ GenBank accession numbers } \\
\hline & & $\mathrm{COI}$ & Cyt B & $12 S$ & $16 S$ \\
\hline ursina $2 \quad f \quad$ f & CER & FJ656179 & FJ656191 & FJ222681 & FJ222712 \\
\hline \multicolumn{6}{|c|}{ /IT: U, Lazio. Percile (RM); Apr. 4, 1999} \\
\hline nigrohirta $1 \mathrm{~m}$ & $\mathrm{TSCH}$ & - & - & FJ222682 & FJ222713 \\
\hline \multicolumn{6}{|c|}{ /DE: BW-Horb MU76 Ihlinger Berg; Apr. 15, 1991} \\
\hline $\begin{array}{l}\text { nigrohirta } 2 \quad \mathrm{~m} \\
\text { ISK: Biele Karpaty, Mravcov }\end{array}$ & $\begin{array}{l}\text { ČEP } \\
\text { pr. } 24,199\end{array}$ & FJ656180 & FJ656192 & FJ222683 & FJ222714 \\
\hline \multicolumn{6}{|l|}{ (Tachina) } \\
\hline grossa 1 f & ČEP & - & - & FJ222684 & FJ222715 \\
\hline \multicolumn{6}{|c|}{ ISK: Klačno (Zlatno); July19, 1992} \\
\hline \multicolumn{6}{|c|}{ ISK: Višňové nr. Nové Mesto (7272), distr. Trenčín; July 20, 1996} \\
\hline \multicolumn{6}{|l|}{ (Echinogaster) } \\
\hline praeceps $1 \quad \mathrm{f}$ & CER & FJ656181 & FJ656193 & FJ222686 & FJ222716 \\
\hline \multicolumn{6}{|c|}{ /IT: Sicilia, Parco d. Madonie, Piano Zucchi, 1,075m, July 29, 2005} \\
\hline \multicolumn{6}{|c|}{ /ES: Prov. Gerona, 3-5 km, SE, L'Escala; May 27, 1998} \\
\hline \multicolumn{6}{|l|}{ Outgroups } \\
\hline \multicolumn{5}{|c|}{ /CZ: S. Moravia, 7367, Lanžhot, Soutok, lužní louka; Aug. 25, 1992} & FJ222718 \\
\hline $\begin{array}{l}\text { Gymnocheta viridis } \\
\text { /CZ: S. Moravia, Pavlovské }\end{array}$ & $\begin{array}{l}\text { VAŇ } \\
y, \text { Kotel ste }\end{array}$ & May 4, 199 & - & FJ222689 & FJ222720 \\
\hline $\begin{array}{l}\text { Linnaemya picta } \\
\text { /CZ: S. Moravia, Pavlovské }\end{array}$ & $\begin{array}{l}\text { Rozk. } \\
\text { y, steppe; }\end{array}$ & $\overline{13}, 1998$ & - & FJ222690 & FJ222719 \\
\hline $\begin{array}{l}\text { Nowickia ferox } \\
\text { /CZ: Brno, Hády Hill, } 1987\end{array}$ & Rozk. & - & - & FJ667756 & FJ667754 \\
\hline $\begin{array}{l}\text { Peleteria varia } \\
\text { /SK: Vihorlat, } 1986\end{array}$ & ČEP & - & - & FJ667757 & FJ667755 \\
\hline
\end{tabular}

ICH - Ryoko T. Ichiki; Japan International Research Center for Agricultural Sciences, Ohwashi, Tsukuba, Ibaraki 305-8686, Japan; richiki@jircas.affrc.go.jp

TSCH - Hans-Peter Tschorsnig, Staatliches Museum für Naturkunde, Rosenstein 1, 70191 Stuttgart, Germany; tschorsnig.smns@naturkundemuseum-bw.de VAŇ - Jaromír Vaňhara (corresponding author) ZIE - Joachim Ziegler, Museum für Naturkunde. Leibniz-Institute for Research on Evolution and Biodiversity at the Humboldt University Berlin, Invalidenstrasse 43, 10115 Berlin, Germany; Joachim.Ziegler@MUSEUM.HU-Berlin.de

Deep focus micrographs were prepared using a stereomicroscope Olympus SZX 12 and attached digital camera Color View III $\mu$. Superposition from micrograph layers was achieved by SW Helicon-Focus and subsequently they were adjusted by Paint Shop Pro 8 graphic software. In one case it was not possible to study all structures in the "best position" and that is why sternite 5 was separated from the rest of the postabdomen and both parts were photographed separately (see Fig. 13b).

Pen drawings, prepared by H. Novotná and R. Rozkošný, are based on the original micrographs created by $\mathrm{H}$. Novotná and M. Tkoč and were completed in close cooperation with V. Procházková, Brno.

The male postabdomen of 100 mostly pinned males was studied (Table 1). Male terminalia were boiled in $10 \%$ solution of $\mathrm{KOH}$ for $15 \mathrm{~min}$. and then washed. For the bacilliform sclerites temporary slides in glycerine were prepared. Other structures were kept in glycerine and studied in situ.

For cladistic analysis 11 characters of the 
male postabdomen were chosen. Characters 6, 7 and 10 were encoding like multistate characters, from them 7 and 10 were unordered (Fitch optimalization) and character 6 was ordered (Wagner optimalization). By the analysis of the matrix were obtained 6 economy-sized cladograms with length $\mathrm{L}=19$, consistent index $\mathrm{CI}=$ 0.78 and retention index $R I=0.93$. Strict consensus from these 6 trees has the following parameters: $\mathrm{L}=21, \mathrm{CI}=0.71, \mathrm{RI}=0.90$.

The genus Tachina has never been tested by cladistic analysis before and that is why several outgroups were used: a) from the same tribe Tachinini: Germaria ruficeps (Fallén, 1820), Nowickia ferox (Panzer, 1809), Peleteria rubescens (Robineau-Desvoidy, 1830), and Schineria tergestina Rondani, 1859; b) from the same subfamily Tachininae: Gymnocheta viridis (Fallén, 1810) (Ernestiini), Linnaemya picta (Meigen, 1824) (Linnaemyini); c) and from a different subfamily: Winthemia variegata (Meigen, 1824), Gonia divisa Meigen, 1826 (Exoristinae). The sister group of Tachinidae is probably Rhinophoridae, from which Stevenia atramentaria (Meigen, 1824) was a basal outgroup of the phylogenetic tree.

The analyses were done using Nona 2.0 (Goloboff 1993) and Winclada 1.00 .08 (Nixon 2002) with the heuristic algorithm and the following setup: maximum trees to keep $=1,000$; number of replications $=15$; starting trees per replication $=5$; search strategy $=$ multiple $\mathrm{tbr}+\mathrm{tbr}$.

Molecular analyses were based on four mitochondrial markers CO I, Cyt b, 12S and 16S rDNA for subgeneric level and two markers $12 \mathrm{~S}$ and 16S rDNA for the species analyses (for GenBank accession numbers, see Table 2). The DNA was extracted following the protocol in Tóthová et al. (2008).

Partial sequences of the mitochondrial $12 \mathrm{~S}$ rRNA (cca 375 bp) and 16S rRNA genes (cca 350 bp) were amplified using primers $12 \mathrm{Sma}\left(5^{\prime}\right.$ CTGGGATTAGATACCCTGTTAT) and 12Smb (5' CAGAGAGTGACGGGCGATTTGT) (Cook et al. 2004), and modified primers mt32 (5' CAACATCGAGGTCGC) and mt34 (5' TTGACCGTGCAAAGGTAG) (Nirmala $e t$ al. 2001). Amplification primers for Cyt b were selected from Krzywinski et al. (2001) as follows: cytbF 5'-GGACAAATATCATTTTG-
AGGAGCAACAG-3' and cytbR 5'-ATTACTCCTCCTAGCTTATTAGGAATTG-3' (cca $450 \mathrm{bp}$.). For the mitochondrial COI, gene the primers 911 5'-TTTCTACAAATCATAAAGATATTGG-3' and 912 5'-TAAACTTCAGGGTGACCAAAAAATCA-3'. (Guryev et al. 2001) were used to amplify the cca $650 \mathrm{bp}$ long fragment. PCR amplifications were carried out in a $20 \mu \mathrm{l}$ reaction mixture containing $1 \mathrm{x}$ PCR buffer (Fermentas), 2mM MgCl2, 1.2U Taq polymerase (Fermentas) and $4 \mu \mathrm{M}$ of each primer. Temperature cycling generally consisted of a $2 \mathrm{~min}$. initial denaturation at $94^{\circ} \mathrm{C}$, followed by 38 cycles including $94^{\circ} \mathrm{C}$ for $30 \mathrm{~s}, 53^{\circ} \mathrm{C}$ for 45 $\mathrm{s}$ (for $16 \mathrm{~S}$ ) and $72^{\circ} \mathrm{C}$ for $1 \mathrm{~min} .30 \mathrm{~s}$ and final extension at $72^{\circ} \mathrm{C}$ for $7 \mathrm{~min}$. The annealing temperature for segment of $12 \mathrm{~S}$ was $55^{\circ} \mathrm{C}$, for cyt b $50^{\circ} \mathrm{C}$ and for the COI $47^{\circ} \mathrm{C}$. PCR reactions were performed in EpGradientS (Eppendorf) thermal cycler.

PCR products were electrophoresed in $1 \%$ agarose gels, purified using the QIAquick PCR Purification Kit (QIAGEN) and used directly for sequencing. The sequencing reactions were performed in a $10 \mu \mathrm{l}$ reaction mixture using the Big Dye Terminator v. 1.1 chemistry. After the thermocycling, the reactions were purified by EDTA/ethanol precipitation before injection into the ABI 3130 Genetic Analyser (Applied Biosystems).

Sequences were manually processed and contigs assembled using Sequencer v. 4.8 (GeneCodes); alignments and the phylogenetic analyses were conducted using MEGA v. 3.1 (Kumar et al. 2004), MrBayes v. 3.1.1 (Huelsenbeck \& Ronquist 2001) and PAUP* v.4.0b10 (Swofford 2002).

The reconstruction of phylogenetic relationships among subgenera was performed using Bayesian analyses (BA) by MrBayes v. 3.1.1 (Huelsenbeck \& Ronquist 2001). We used the MrModeltest v. 2.2 (Nylander 2004) for testing and choosing the best model for the analyses. The alignment of all four markers of 13 species consisted of $1495 \mathrm{bp}$ (12S 1-317, 16S 318-566, CO I 567-1114, Cyt b 1115-1495) and was conducted using ClustalX (implemented in MEGA). In the alignment of coding genes, the stop-codons were eliminated. The non-coding ones were aligned manually. All the alignments are available upon 
request from A. Tóthová (co-author, see above). In the analysis, we did not exclude the $3^{\text {rd }}$ codon position despite a slight saturation in order not to lose the variable characters. The different codonposition evolutionary rate is implemented in the settings of the analysis. Parameters of the BA were set as follows: memc printfreq $=1000$ samplefreq $=1000$ nchains $=8$ nruns $=2$ temp $=0.05$ swapfreq $=1$ nswap $=2$ printmax $=16$ mcmcdiagn $=$ yes diagnfreq $=1000$ relburnin $=$ yes burninfrac $=$ 0.3 sumt displaygeq $=0.5$ burnin $=300$ sump burnin $=300$. The reliability of the resulting tree topology was determined by $2,000,000$ generations.

For the species analysis of 34 specimens, we performed a maximum parsimony analysis using PAUP. The data matrix consisted of the 12S rRNA and 16S rRNA alignments containing 334 and 343 sites, and 11 morphological characters, respectively. Of the total 688 combined characters 110 were parsimony-informative. Parsimony analysis of the character state matrix was performed using the program PAUP* version 4.0b10 (Swofford 2002). A heuristic search with stepwise addition was implemented to find the most parsimonious trees using random addition sequence of taxa, tree-bisection-reconnection (TBR) branch swapping and 1,000 random replications. Cladogram estimates (or statistics) such as consistency index $(\mathrm{CI})$, retention index (RI) and rescaled consistency index (RC) were used to assess the fit of data to the cladograms. Branch support for each clade was calculated via nonparametric bootstrapping with 1,000 replications. The resultant tree was edited in TreeView (Page 1996) and the layout was prepared using Adobe Photoshop 8.0 CS. Flook \& Rowell (1997) have shown that combining $12 \mathrm{~S}$ and $16 \mathrm{~S}$ rRNA sequences for intra-ordinal phylogenetic analyses of insects improves consistency. Cook et al. (2004) supported this statement using the same combination of gene markers in their study on relationships of critical genera of Phoridae and related families of Aschiza.

\section{Results}

\subsection{Structural characters of male postabdomen at the genus level}

\subsubsection{Genus Tachina Meigen, 1803}

Type species. Musca grossa Linnaeus, 1758

The general form of male terminalia of $T a$ china is represented by a hypopygium circumversum (a rotation through $360^{\circ}$, Griffiths 1972), a condition that is characteristic for all Cyclorrhapha. The male postabdomen is partly stored below tergite 5 . This typical position is reflexed due to an antero-ventral turnover of the distal part of the abdomen, with terminalia partly nesting below abdominal tergite 5 . Tergite 6 is completely reduced. Segment $7+8$ (=syntergosternite $7+8)$ is an arched structure between tergite 5 and epandrium, asymmetrical due to a short apophyse on the left side and a long apophyse on the right side. Spiracle 6 is situated laterally in the membrane but in a small, distinctly sclerotized plate, perhaps a rudiment of tergite 6 , in $T$. grossa. Spiracle 7 is placed anterolaterally in segment $7+8$. Sternite 5 is more differentiated and larger than the preceding sternites, with a V-shaped or sometimes at least partly U-shaped midincision at the posterior margin and more or less prominent posterior lobes. The anterior margin of the basal plate is usually extending in partly membranous projections at each corner; see Tschorsnig (1985: 20 Fig. 31). Sternite 6 is asymmetrical, with the wide and long left part, slightly overlapping the short apophyse of segment $7+8$, and more or less firmly articulated with it. The right part of sternite 6 is bowl-shaped and narrowly separated by a membrane from a long apophyse of segment $7+8$. The epandrium (tergite 9) is spherical. Segment 7+8 also with a well-developed apophyse at the right side, see Tschorsnig (1985: 14 and 95). The syncercus originates through a medial fusion of both cerci, the dorsal (outer) margin in lateral view often more or less concave; in caudal view tapered towards an apical spine. The surstylus is well-developed, in some species (Eudoromyia) with a distinctly delimited basal plate and an apical lobe. The apical lobe separated by a more or less distinct angular lateral incision (visible in caudal view); the basal plate more or less firmly fused 


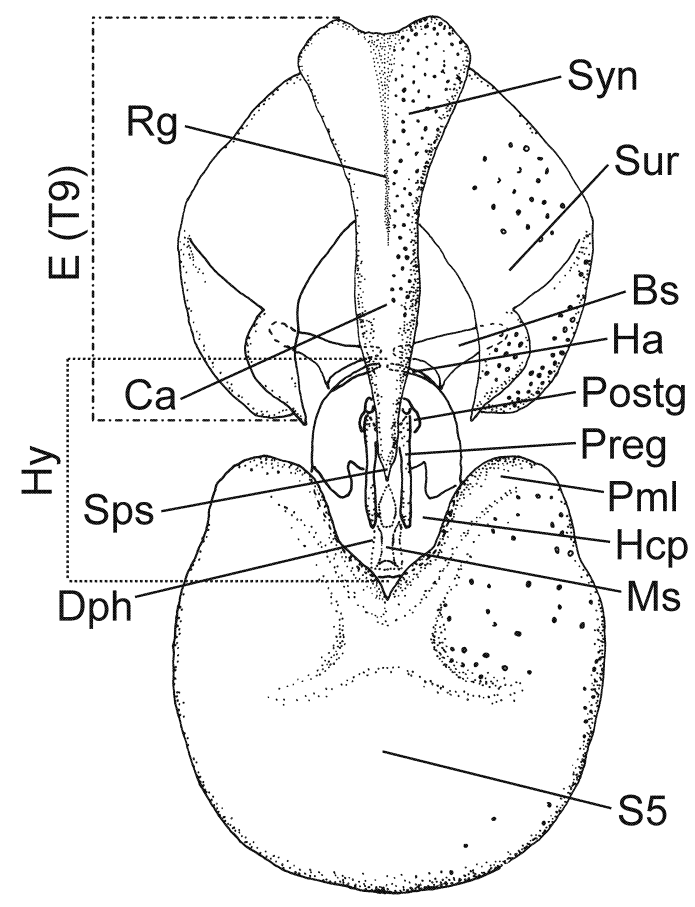

Fig 1. Idealized scheme of Tachina (Eudoromyia) male postabdominal structures, caudal view. Bphbasiphallus, Bs-bacilliform sclerite, Ca-callus of syncercus, Dph-distiphallus, E (T9) -epandrium (tergite 9), Ea-ejaculatory apodeme, Ha-hypandrial arm, Hcp-hypandrial central plate, Hy-hypandrium, Ms-medial stripe of distiphallus, Pha-phallapodeme, PI-posterior lobe of sternite 5, Postg-postgonite, Pregpregonite, Rg-ridge of syncercus, Sps-spine of syncercus, Sp 6-spiracle 6, Sp 7-spiracle 7, Sts 7+8sternite 7+8 (=syntergosternite 7+8), Sur-surstylus, Syn-syncercus, S5-sternite 5, S6-sternite 6.

with the epandrium but only membranously connected with the basal part of the syncercus; apical lobe free from epandrium, mostly pointed and more or less subtriangular but sometimes bent inwards and bicuspidate. The arms of the hypandrium (=sternite 9) are converging but not fused. The bacilliform sclerites (=divided sternite 10) are plate-like and situated inside the epandrium, attached proximally to the hypandrial arms. The proximal end of each bacilliform sclerite has two distinnt nroiestinne the unner of wxhich mav he an-

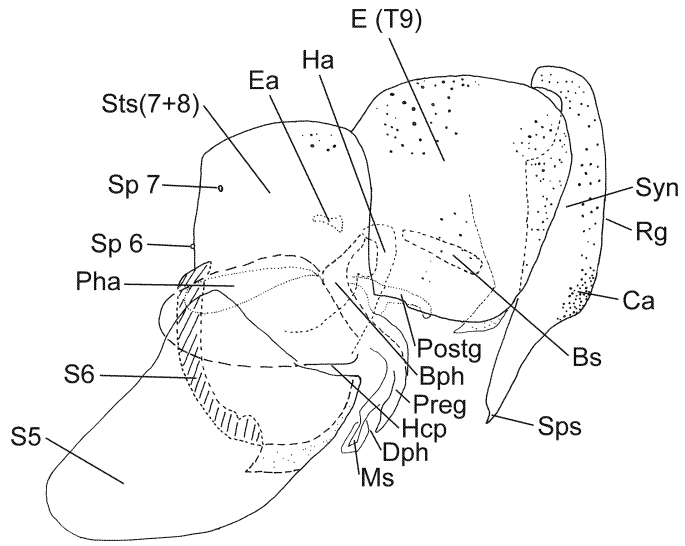

Fig 2. Idealized scheme of Tachina (Eudoromyia) male postabdominal structures, lateral view. For abbreviations see Fig. 1.

andrial middle plate (see Tschorsnig 1985: 34). The postgonite (=paramere) is straight and distally bent into a short rounded apex. The basiphallus is tubular, long and curved, articulated with the hypandrial arms basally (regarded as a synapomorphy by Tschorsnig 1985: 95), and flexibly linked with the distiphallus by the dorsal sclerite. The epiphallus is reduced. A median projection on the dorsal sclerite of the distiphallus is not developed. The medial stripe is a well differentiated sclerotized medioventral part of the distiphallus. The ventral membrane of the distiphallus extends to a lateral fold on each side provided with microscopically small denticles. The phallapodeme is elongated and depressed laterally, attached to the basal part of the basiphallus by a flat projection (=intermedium of Tschorsnig). The ejaculatory apodeme of the sperm pump is small, of a flat clavate form.

\subsection{Structural characters of male postabdomen of Tachina at the subgenus level}

The significant characters on the male postabdomen are situated on epandrium, syncercus, surstylus, and bacilliform sclerite (Figs 1-3). Tarhina is cuhdivided hare into 4 cuhroenera as- 
Fig 3. Idealized scheme of Tachina (Eudoromyia) male postabdominal structures Inner copulatory organ and position of bacilliform sclerites. - a. Ventral view. - b. Lateral view. - c. Aedeagus, lateral view. Bphbasiphallus, Bsbacilliform sclerite, Dph-distiphallus, Eaejaculatory apodeme, Ha-hypandrial arm, Hyhypandrium, Ms-medial stripe of distiphallus, Pha-phallapodeme, Postg-postgonite, Pregpregonite, Sursurstylus.

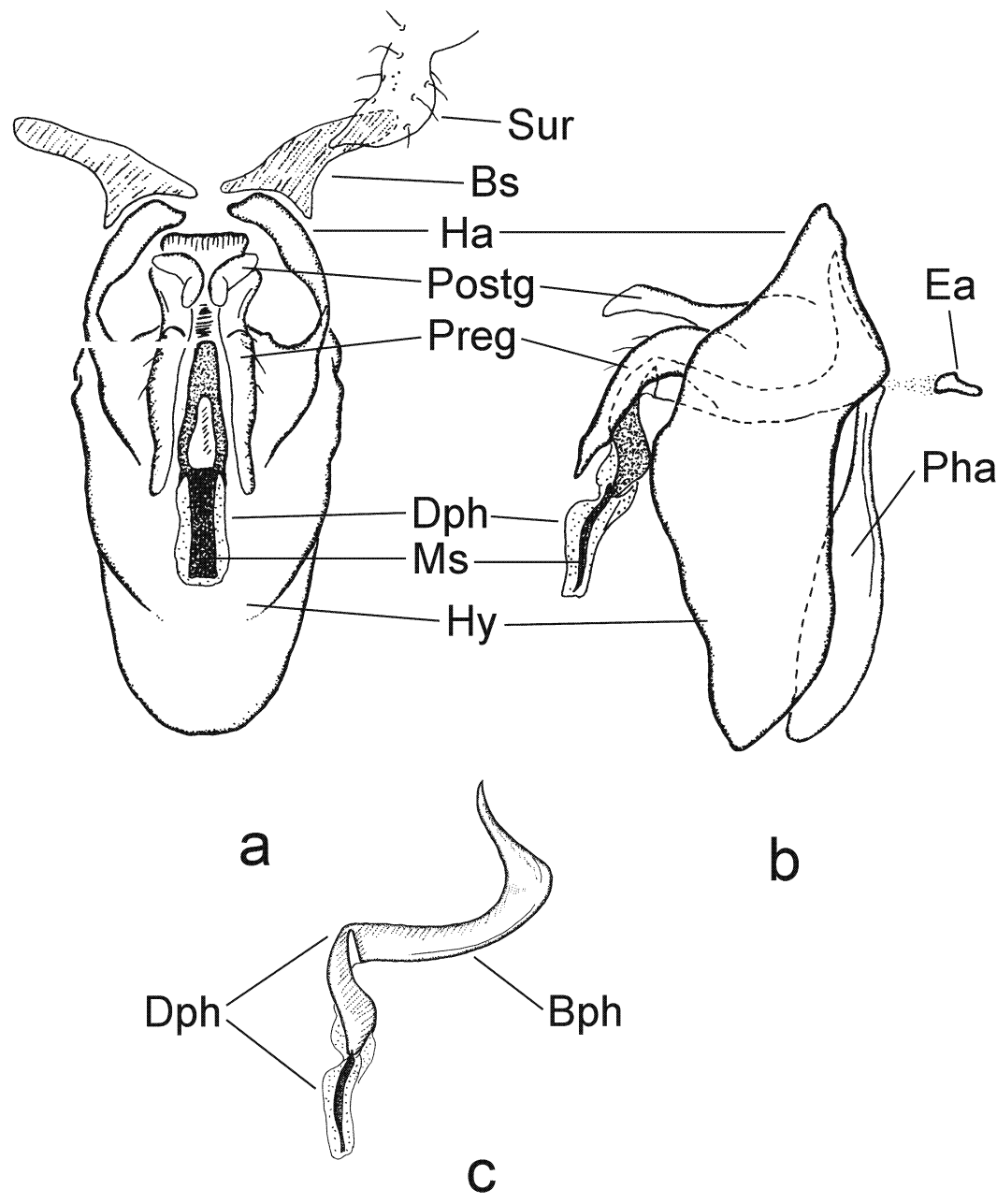

3.2.1. Subgenus Eudoromyia Bezzi, 1906; (Figs 4-11)

Type species. Eudora illustris RobineauDesvoidy, 1863 (= Echinomyia casta Rondani, 1859)

Syncercus in caudal view usually considerable extending below apices of surstyli (but only slightly in $T$. canariensis); syncercus gradually tapered in distal half or swollen at about middle and forming a more or less distinct callus.

Surstylus in strictly caudal view extending below lower margin of epandrium; outer margin of surstylus with an angular incision or at least markedly undulating apical lobe well-delimited, triangular and with a single tip.

Bacilliform sclerite with a slender but apically rounded upper projection.
3.2.2. Subgenus Servillia Robineau-Desvoidy, 1830; (Figs 12-14)

Type species. Tachina ursina Meigen, 1824

Syncercus in caudal view distinctly reaching beyond level of apices of surstyli; in lateral view with slender apical part occupying nearly distal half, outer margin gradually tapered (T. ursina) or distinctly concave.

Surstylus in strictly caudal view as long as or shorter than epandrium, lateral incision at most slightly undulating; apical lobe with a single tip. If viewed in a slightly more ventral position, the surstylus of $S$. ursina may be interpreted as undulating.

Bacilliform sclerite with a long and pointed upper projection. 
a

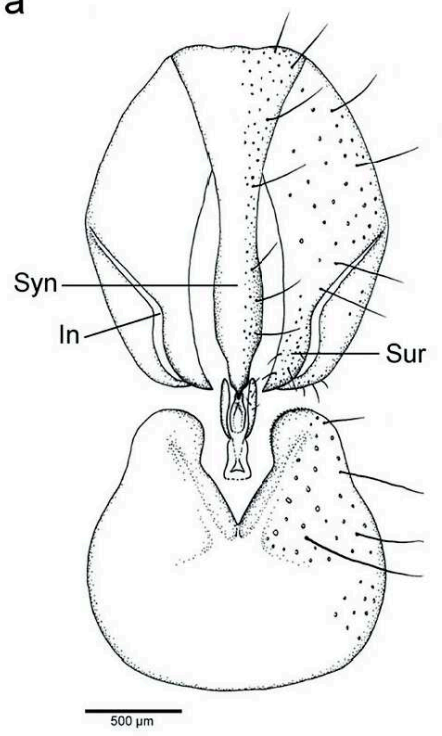

C

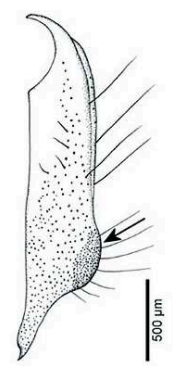

e

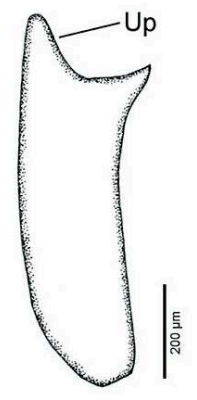

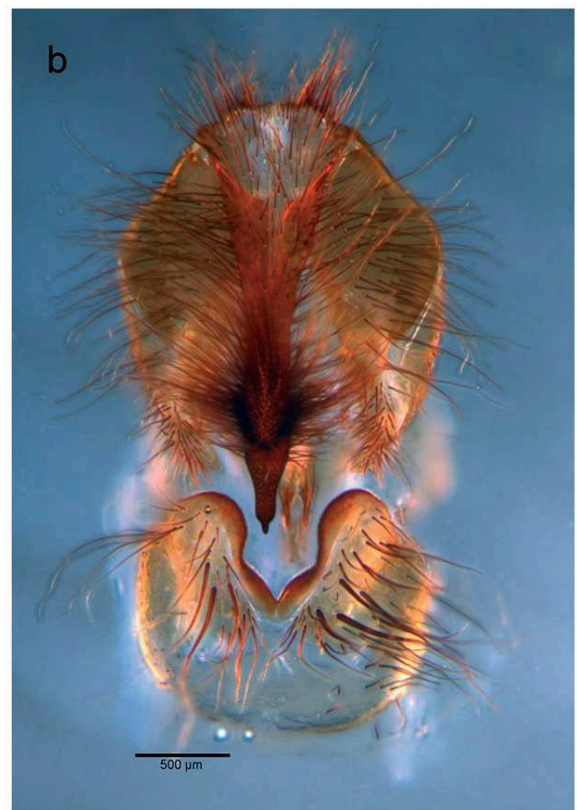

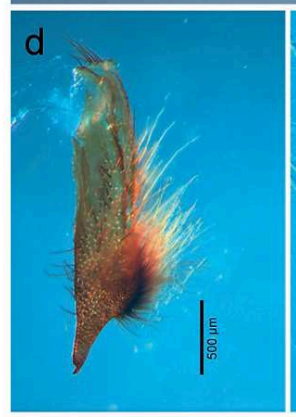

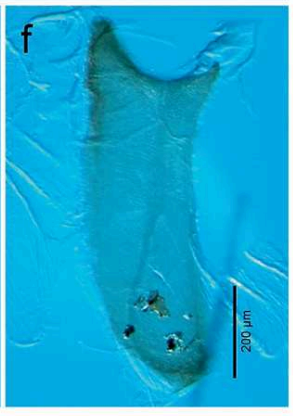

Fig 4. Tachina (Eudoromyia)

canariensis. $-a, b$. Male postabdomen, caudal view. $-\mathrm{c}$, d. Syncercus, lateral view. $-\mathrm{e}, \mathrm{f}$. Bacilliform sclerite. In-incision, Sursurstylus, Synsyncercus, Up-upper projection.

\subsubsection{Subgenus Tachina s.str.; (Fig. 15)}

Type species. Musca grossa Linnaeus, 1758

Epandrium higher than wide in caudal view; in lateral view with upper posterior corner at an almost right angle.

Syncercus in caudal view massive, distinctly extending beyond lower margin of epandrium; in lateral view concave in middle of inner side; broader basal part occupying basal two thirds; apical part separated by a relatively deep caudal emargination; short distal part compressed laterally; apical spine long and almost straight.

Surstylus in caudal view with apical part markedly bent inwards, bicuspidate apically with upper lobe somewhat larger than lower one.

Bacilliform sclerite with a wide and broadly rounded upper projection.

\subsubsection{Subgenus Echinogaster Lioy, 1864;} (Fig. 16)

Type species. Echinomyia argentifrons Macquart, 1835 (= Tachina praeceps Meigen, 1824)

Epandrium broader than high in caudal view.

Syncercus in caudal view not reaching beyond epandrium, the compressed distal part about as long as the subtriangular basal part; in lateral view with a characteristic appearance, broad along its whole length, dorsal margin only slightly incurved beyond middle, ventral apex more or less lobus-like due to a prolongation of the ventral margin to the tip level with the apical spine.

Surstylus in caudal view with apical part distinctly bent inwards, bifurcated apically.

Bacilliform sclerite with a relatively stout and 
Fig 5. Tachina (Eudoromyia) casta. - a, b.

Male postabdomen, caudal view. $-\mathrm{c}, \mathrm{d}$.

Syncercus, lateral view.

$-e, f$. Bacilliform

sclerite. In-incision.
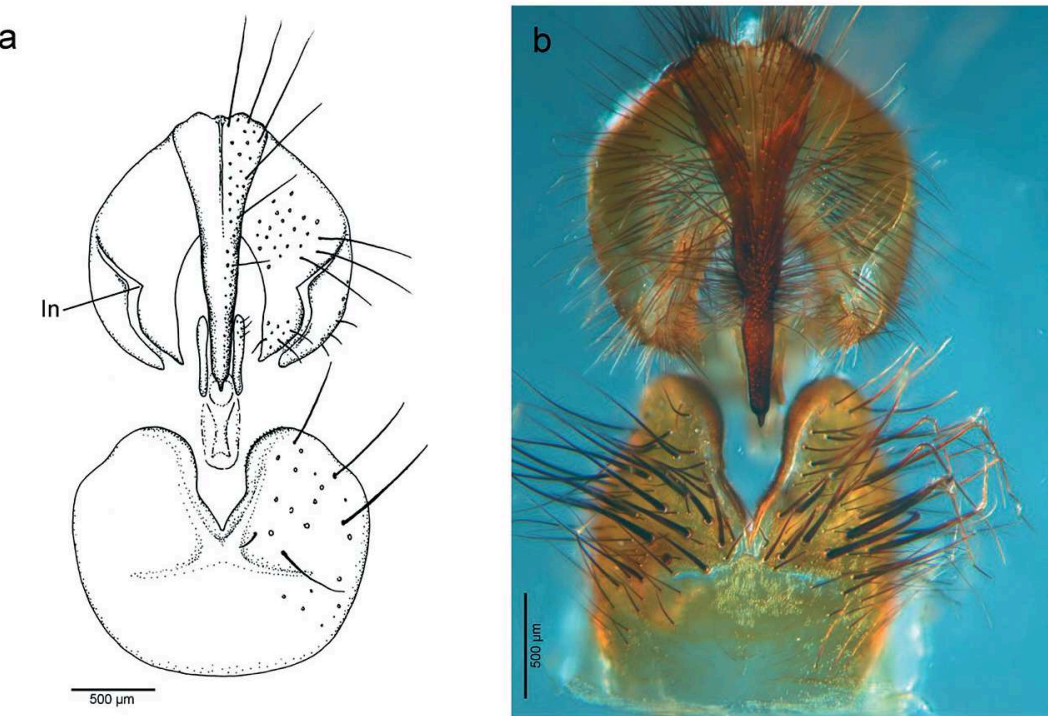

C

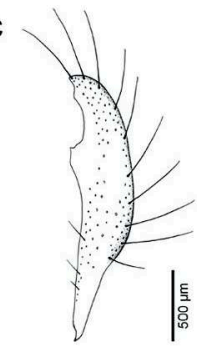

e

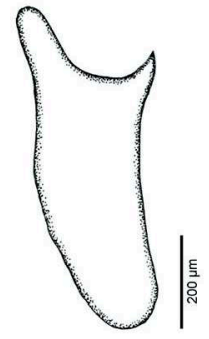

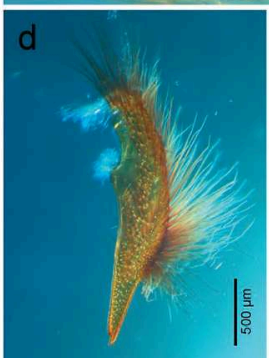

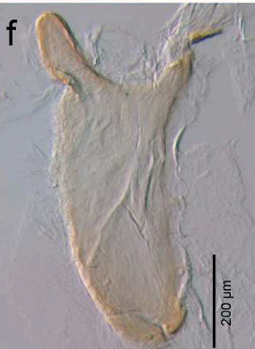

rounded upper projection that is only slightly more slender than in T. grossa.

\subsection{Structural characters of male postabdomen of Tachina at the species level}

\subsubsection{T. (Eudoromyia) canariensis} (Macquart, 1839); (Fig. 4)

Syncercus in caudal view with callus clearly situated beyond middle of syncercus; in lateral view with a prominent dorsal callus; apical (narrow) part of syncercus thus very short, about as long as L' the length of syncercus; ventral (inner) margin with a slight emargination in the ventral margin close to apex.

Surstylus in caudal view with the lateral (outer) incision not as distinct as in other species of this subgenus (undulating as in casta); apical lobe thus appearing relatively long and slender.

Bacilliform sclerite with a relatively short subtriangular (but apically rounded) upper projection.
3.3.2. T. (Eudoromyia) casta Rondani, 1859; (Fig. 5)

Syncercus in caudal view slightly dilated beyond middle and then gradually tapered towards tip; dorsal callus in lateral view thus beyond middle but far from as prominent as in the preceding species. Apical part of syncercus distinctly longer than in T. canariensis; ventral emargination next to the apical spine of similar appearance.

Surstylus in caudal view with a more angular lateral (outer) incision and a slight undulation in the lateral margin (as in $T$. canariensis); apical lobe thus well-delimited and stout.

Bacilliform sclerite with a relatively long and apically rounded upper projection.

\subsubsection{T. (Eudoromyia) corsicana Villeneuve, 1931; (Fig. 6)}

Syncercus in caudal view long and slender; in lateral view gradually tapered towards tip. Apical narrow part relatively long and thus occupying 

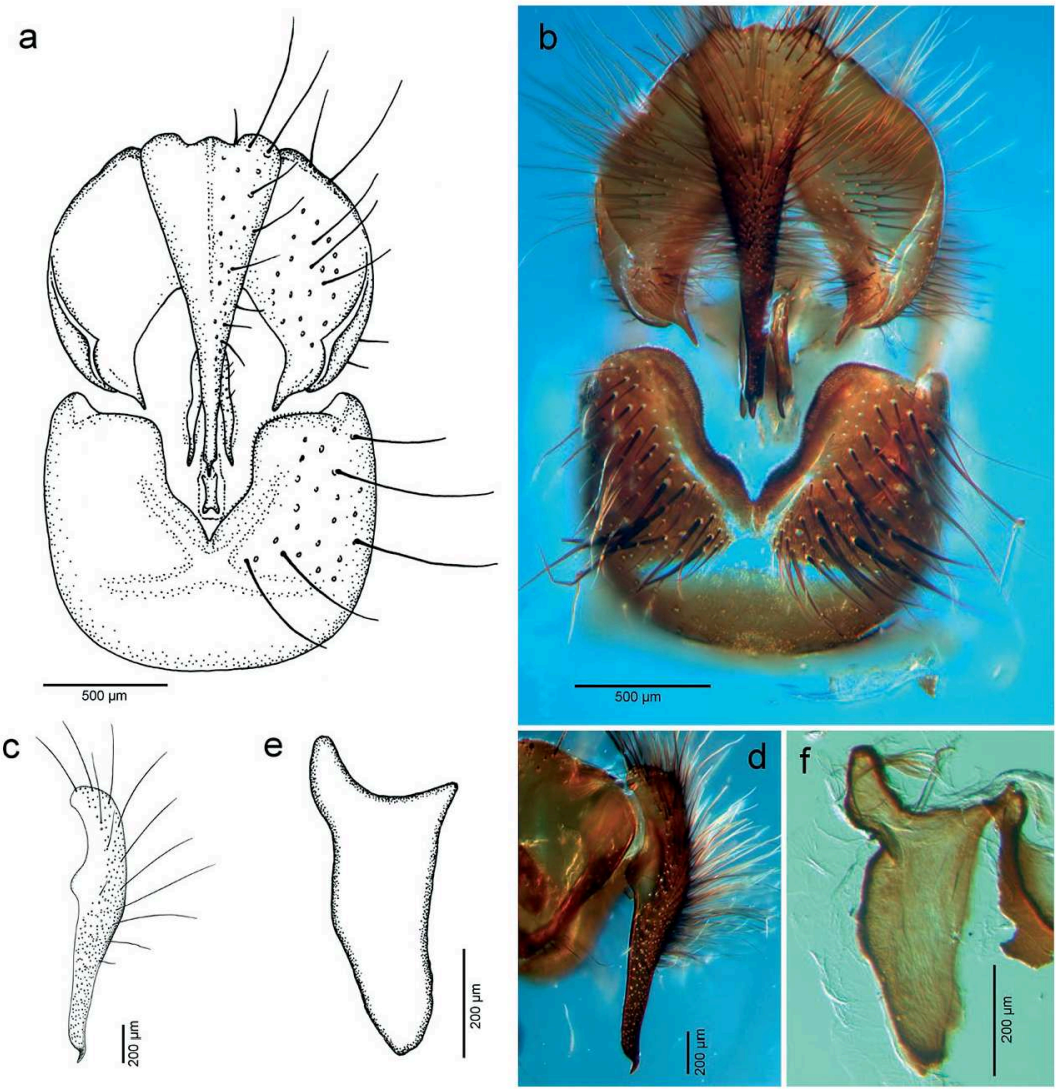

Fig 6. Tachina (Eudoromyia) corsicana. - a, b. Male postabdomen, caudal view. $-\mathrm{c}, \mathrm{d}$. Syncercus, lateral view. $-e$, f. Bacilliform sclerite.

almost distal half; ventral margin distinetly incurved next to the apical spine.

Surstylus in caudal view with a well-defined lateral (outer) incision; apical lobe with a longer and more slender tip than in preceding species. The apical subtriangular part of the surstylus is about as long as stout, as in $T$. casta and moreover in both $T$. casta and $T$. corsicana apparently stouter than in $T$. canariensis, somewhat reaching beyond lower margin of epandrium.

Bacilliform sclerite with upper projections somewhat hook-like but stouter than in following species.

\subsubsection{T. (Eudoromyia) fera (Linnaeus, 1761);} (Fig. 7)

Syncercus in caudal view relatively stout and long, gradually tapered towards tip, distinctly reaching beyond surstyli; submedial dilation (callus) inconspicuous; apical part beyond callus stout and notable broad at base; in lateral view with a distinct dorsal (outer) callus; ventral margin without a distinct emargination next to apical spine.

Surstylus in caudal view with a relatively shallow and wide lateral (outer) incision; apical lobe with a slender projection at tip as in $T$. sp.

Bacilliform sclerite with upper distal projection with a narrowly tapering but rounded tip as in other species of subgenus Eudoromyia.

\subsubsection{T. (Eudoromyia) magnicornis (Zetterstedt, 1844); (Fig. 8)}

Syncercus in caudal view relatively long and gradually tapered towards apex, conspicuously reaching beyond level of lower margin of epandrium; in lateral view with an indistinct dorsal (outer) callus; ventral margin with a concave emargination at about middle and distinctly emarginate next to the apical spine.

Surstylus in caudal view with a deep angular lateral (outer) incision; apical lobe stout and 
Fig 7. Tachina (Eudoromyia) fera. - a, b. Male postabdomen, caudal view. - c, d. Syncercus, lateral view. $-\mathrm{e}, \mathrm{f}$. Bacilliform sclerite. a

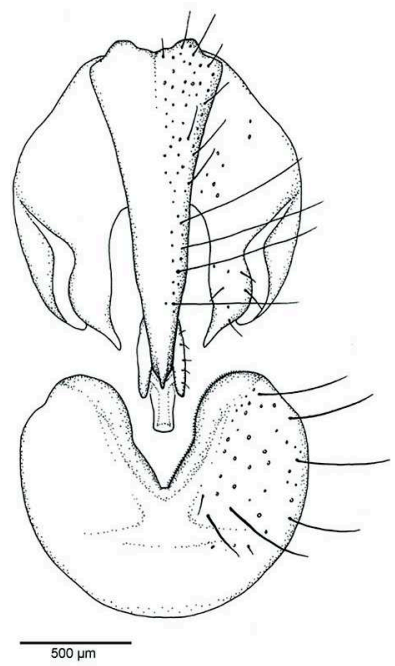

C

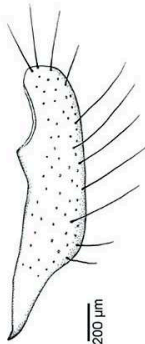

e

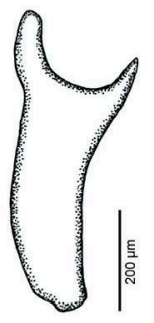

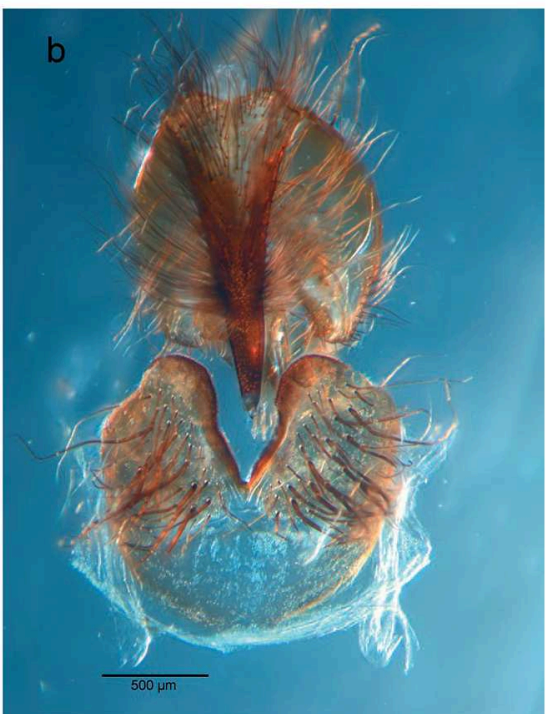

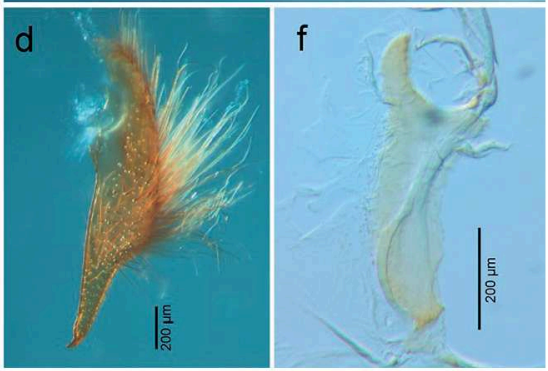

abruptly tapered into a short and slender tip. Surstylus not reaching beyond lower margin of epandrium.

Bacilliform sclerite with upper projection slender and long, rod-like and rounded apically.

\subsubsection{T. (Eudoromyia) nupta (Rondani, 1859);} (Figs 9-10)

Syncercus in caudal view long and slender, distinctly extending below level of lower margin of epandrium; dilated basal part in lateral view barely longer than apical half (central Europe) or distinctly longer (Japan); relative length of apical part is thus different in both, but ventral margin with a distinct emargination next to the apical spine.

Surstylus in caudal view with a distinct lateral (outer) incision; apical lobe stout and massive with a very short tip (central Europe) or a little more slender and with an elongated apical projection (Japan).
Bacilliform sclerite with inner proximal end distinctly tapered in central European specimen and broadly rounded in Japanese ones, upper distal projection straight and somewhat slender in central European specimen.

\subsubsection{T. (Eudoromyia) sp.; (Fig. 11)}

Syncercus in caudal view distinctly dilated directly beyond callus but then gradually narrowing towards the apical spine, extending beyond apices of surstyli; in lateral view relatively slender with the somewhat broadened basal part occupying nearly $2 / 3$ of its length, callus rather prominent but less so compared with T. fera; apical (narrow) part more slender than in T. fera; basal part separated from distal part by rather shallow emargination in dorsal margin; ventral margin with a shallow emargination at about middle and also with a distinct emargination next to the apical spine.

Surstylus in caudal view with an angular and 

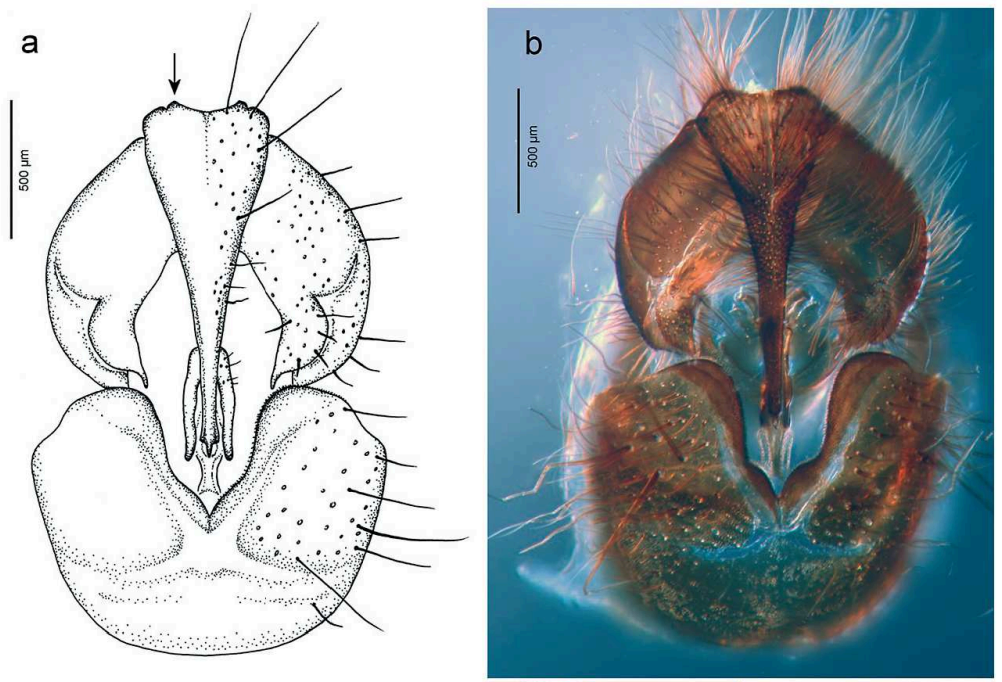

C
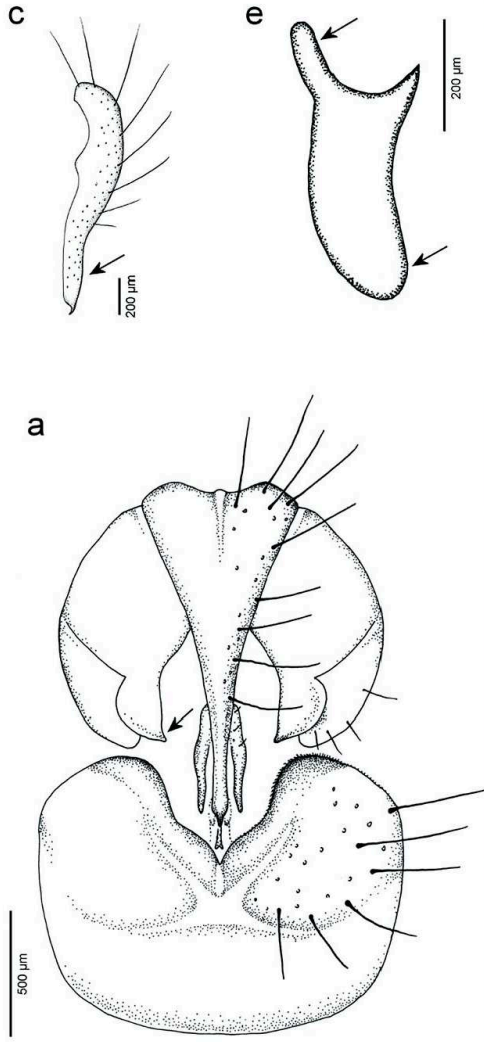

C

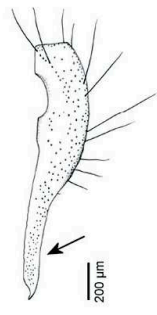

e

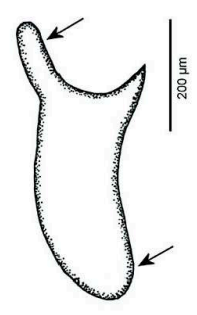

e d
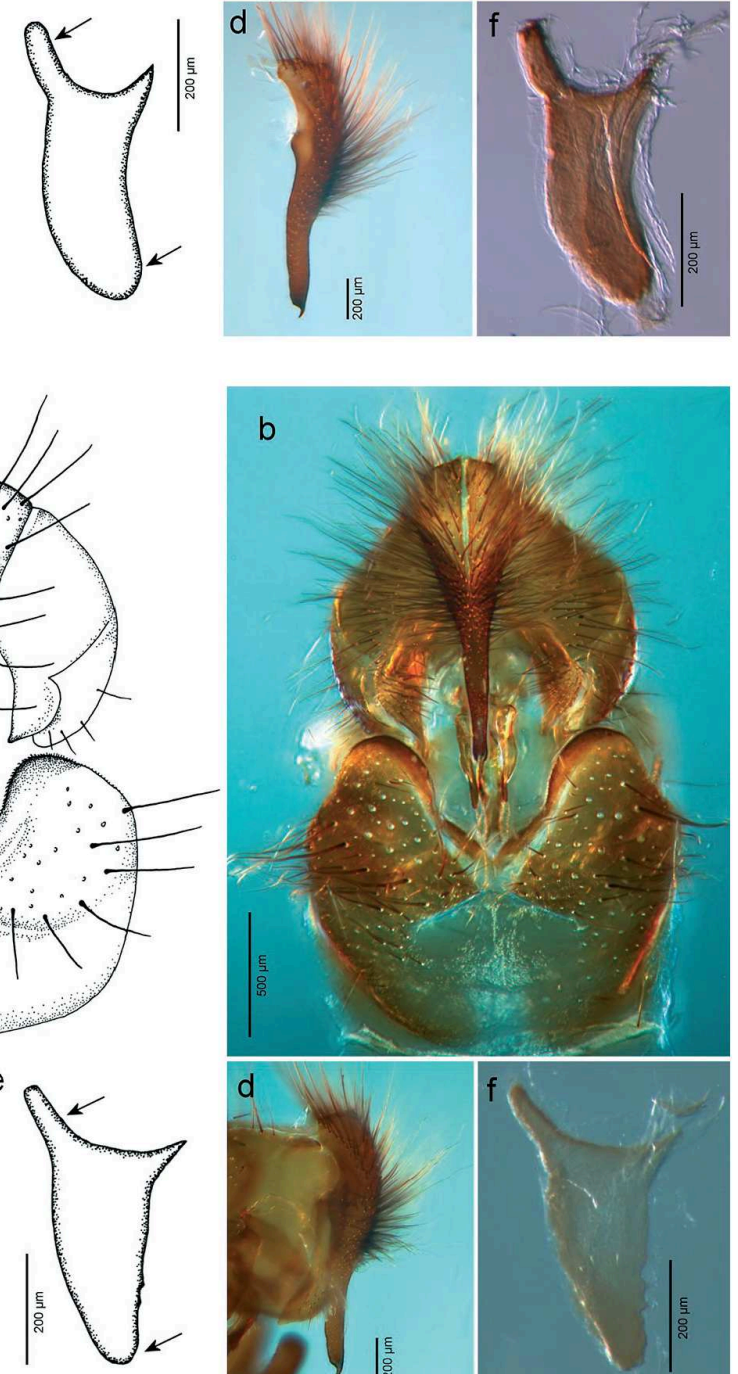

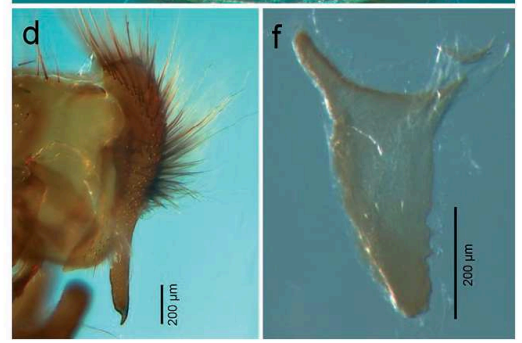

Fig 8. Tachina (Eudoro-

myia) magnicomis. $-a, b$. Male postabdomen, caudal view. - c, d. Syncercus, lateral view. - e, f. Bacilliform sclerite.

Fig 9. Tachina (Eudoromyia) nupta - central Europe. - a, b. Male postabdomen, caudal view. - c, d. Syncercus, lateral view. - e, f. Bacilliform sclerite. 
Fig 10. Tachina (Eudoromyia) nupta - Japan. - a, b. Male postabdomen, caudal view. $-c$, d. Syncercus, lateral view. $-e, f$.

Bacilliform sclerite.

Fig 11. Tachina (Eudoromyia) sp. - a, b. Male postabdomen, caudal view. $-c$, d. Syncercus, lateral view. - e, f. Bacilliform sclerite.

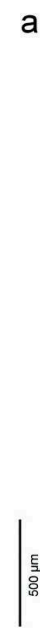

c

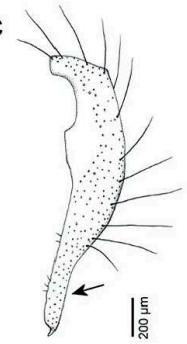

a

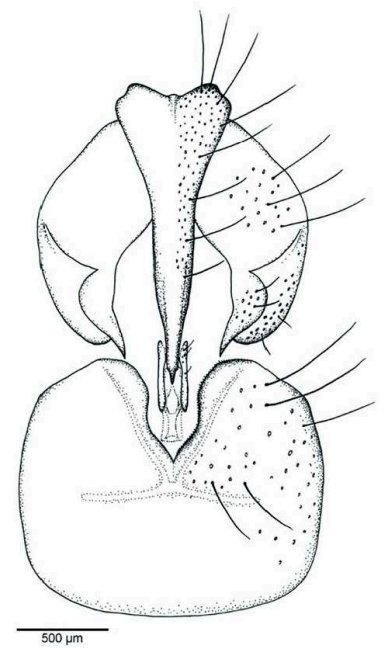

C

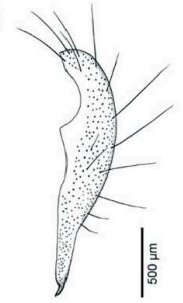

e
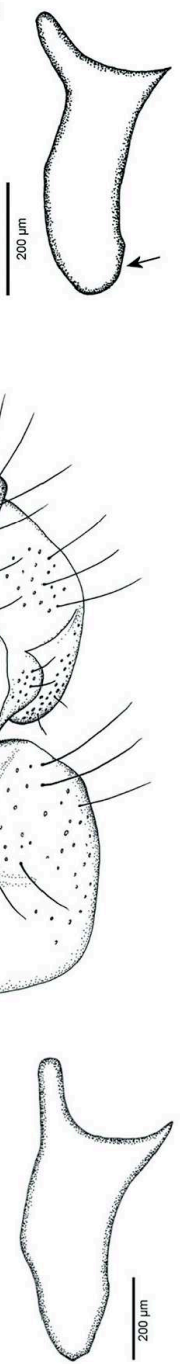
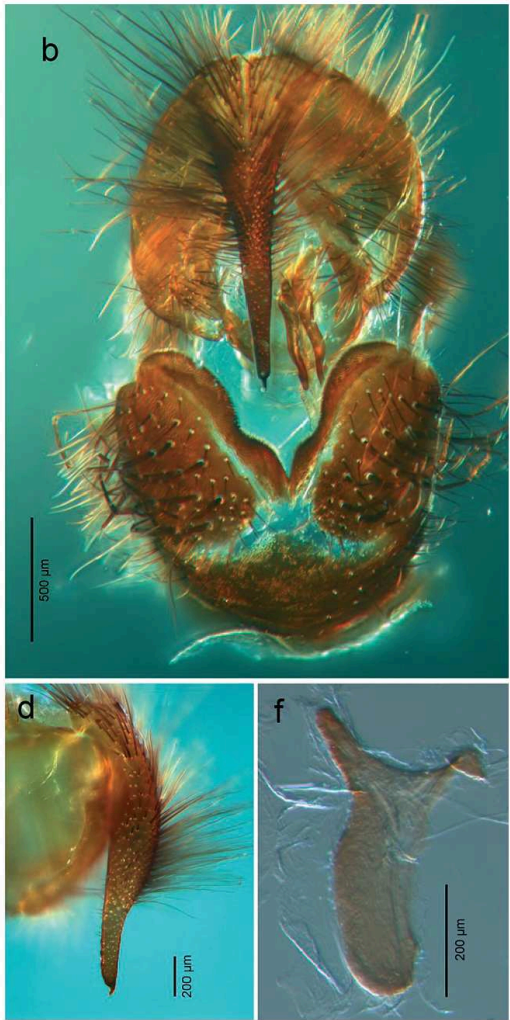

b
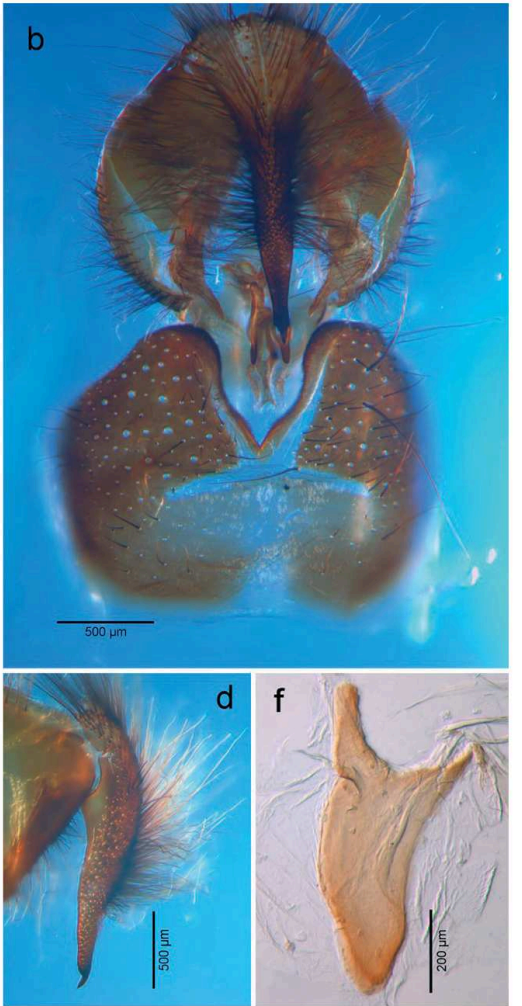
a
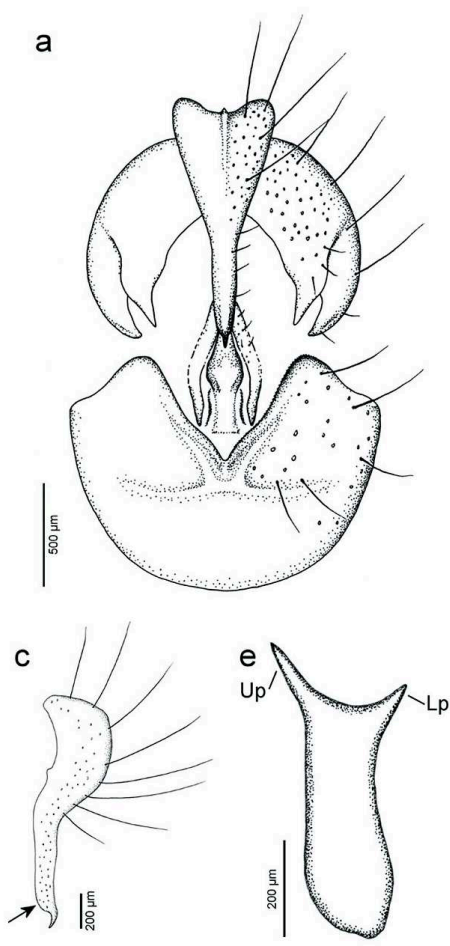

a

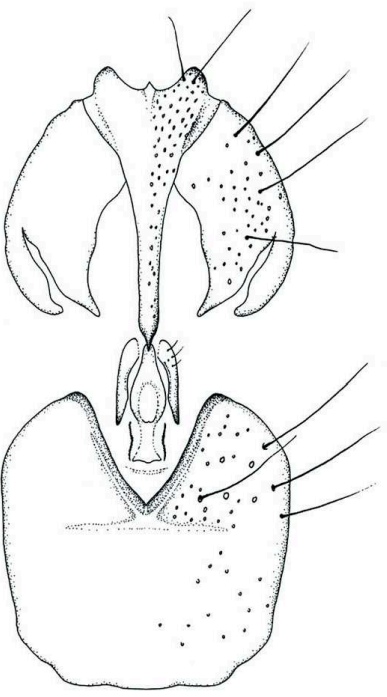

C

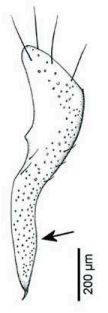

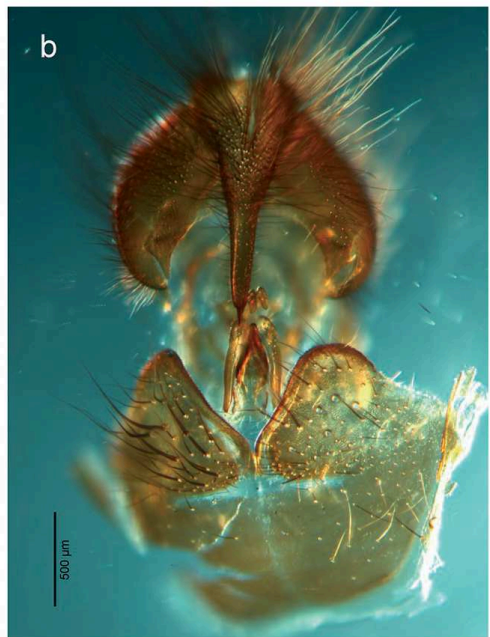
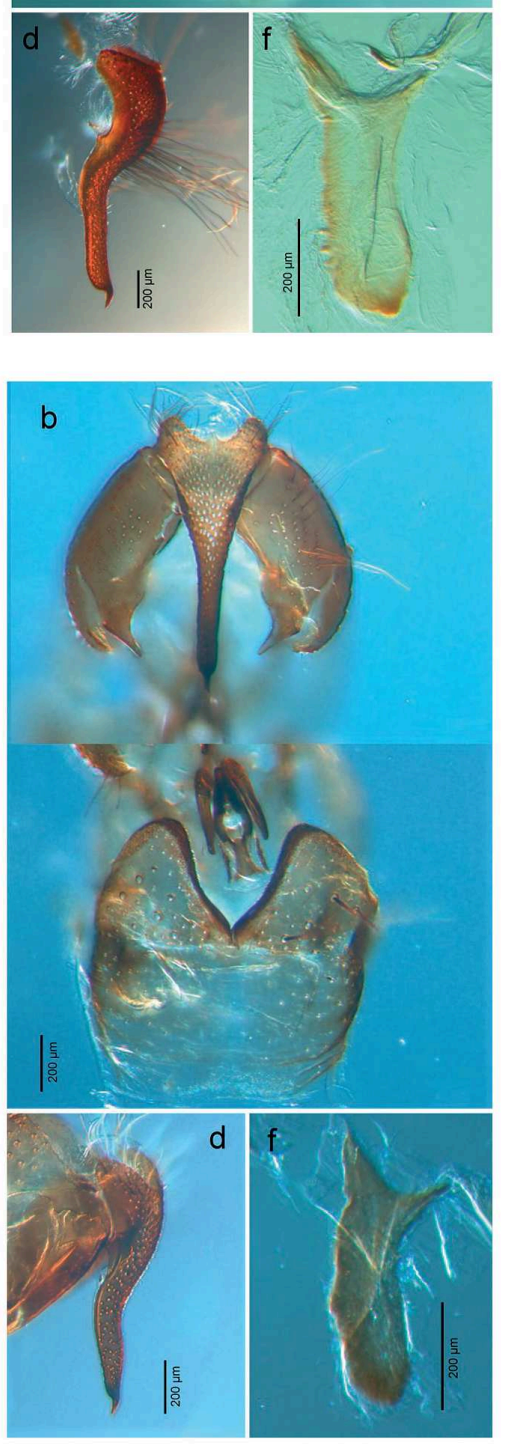

Fig 12. Tachina (Servillia) lurida. - a, b. Male

postabdomen, caudal view. c, d. Syncercus, lateral view. e, f. Bacilliform sclerite. Upupper projection, Lp-lower projection.
Fig 13. Tachina (Servillia) nigrohirta. - a, b. Male postabdomen, caudal view. - c, d. Syncercus, lateral view. $-\mathrm{e}, \mathrm{f}$. Bacilliform sclerite. 
Fig 14. Tachina (Servillia) ursina. - a, b. Male postabdomen, caudal view. $-\mathrm{c}$, d. Syncercus, lateral view. e, f. Bacilliform sclerite.

Fig 15. Tachina (Tachina) grossa. - a, b. Male postabdomen, caudal view. $-c$, d. Syncercus, lateral view. - e, f. Bacilliform sclerite. Dph-distiphallus, Sur-surstylus, Up-upper projection. a

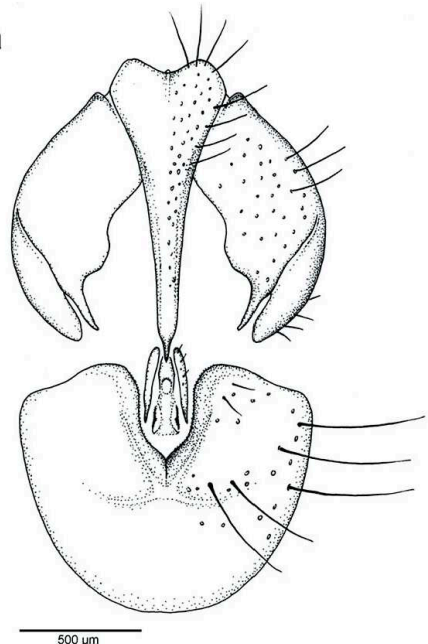

C

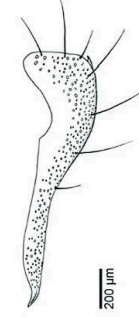

e

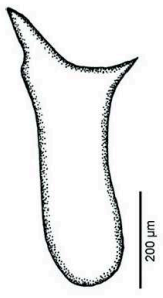

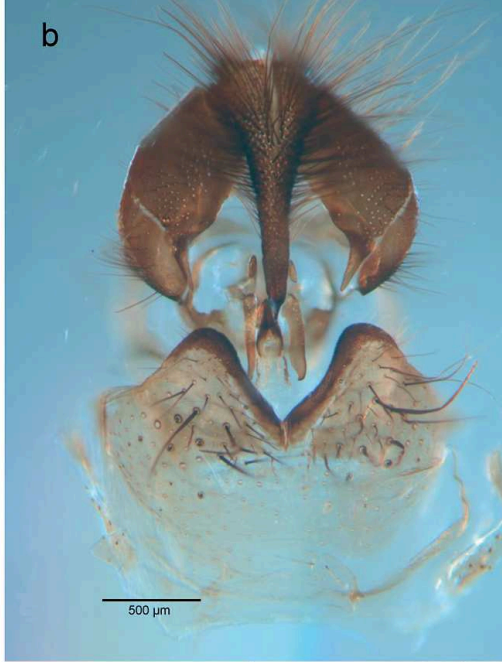
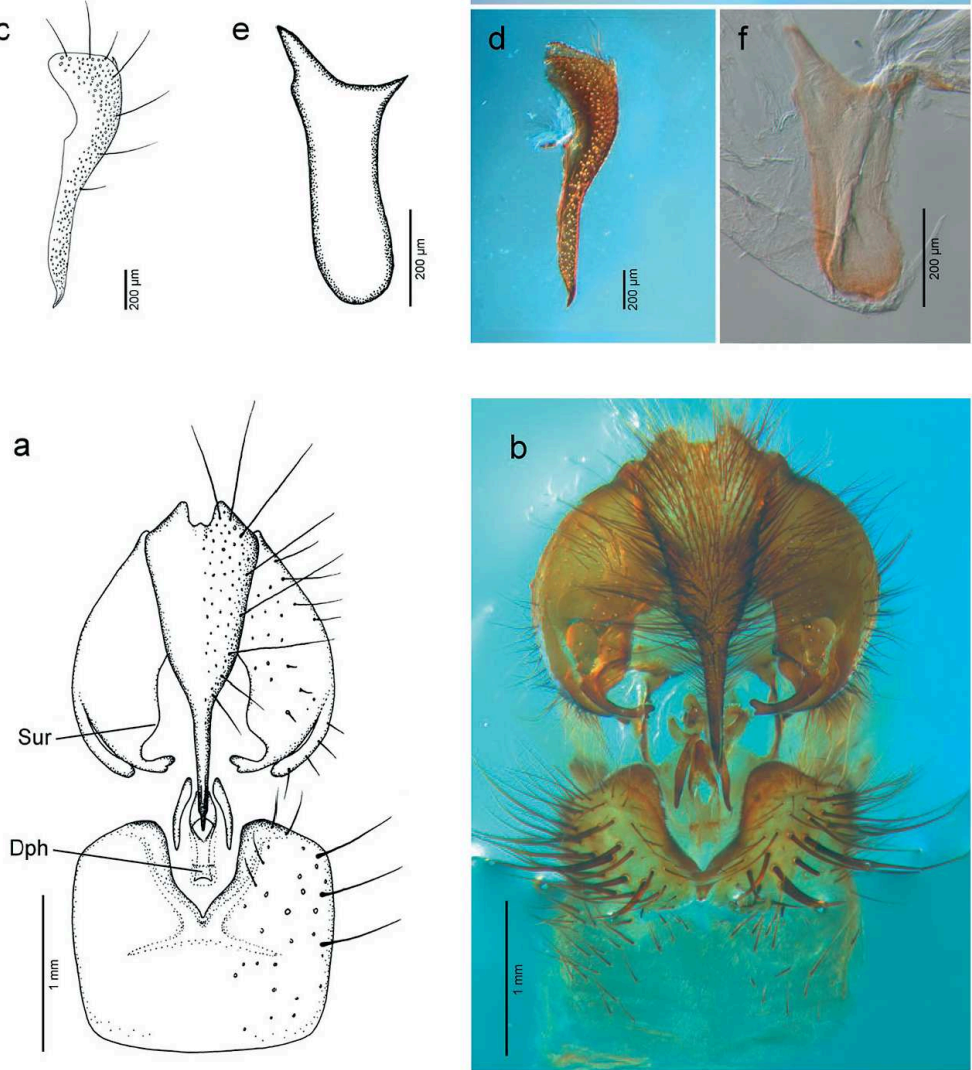

C
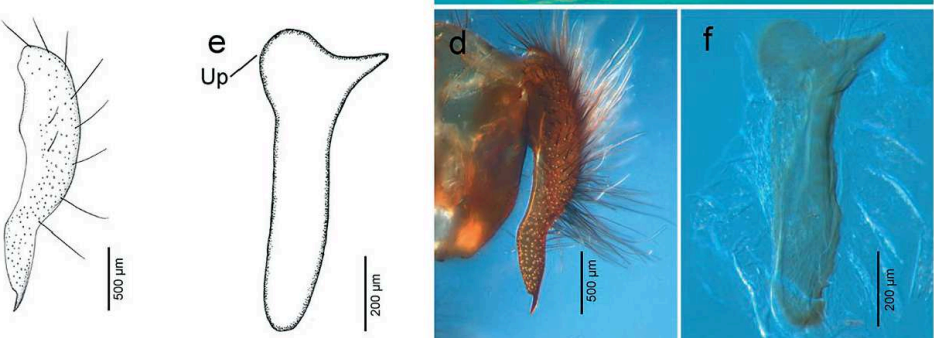
a

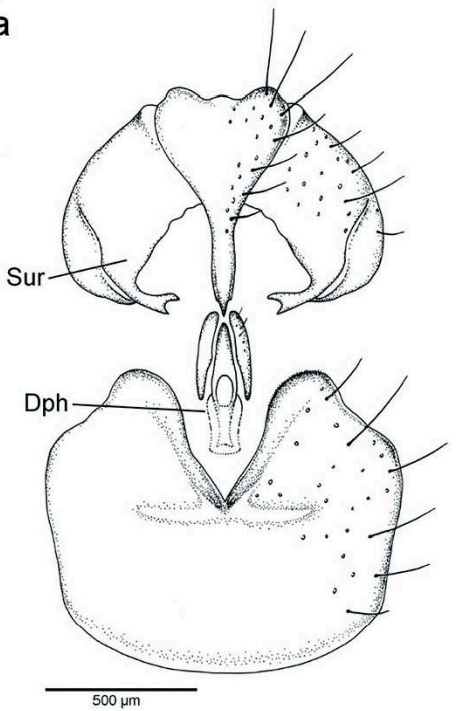

C

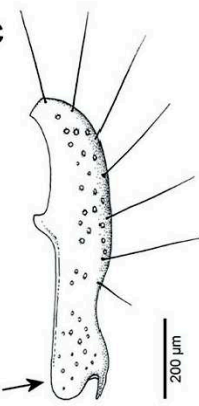

e
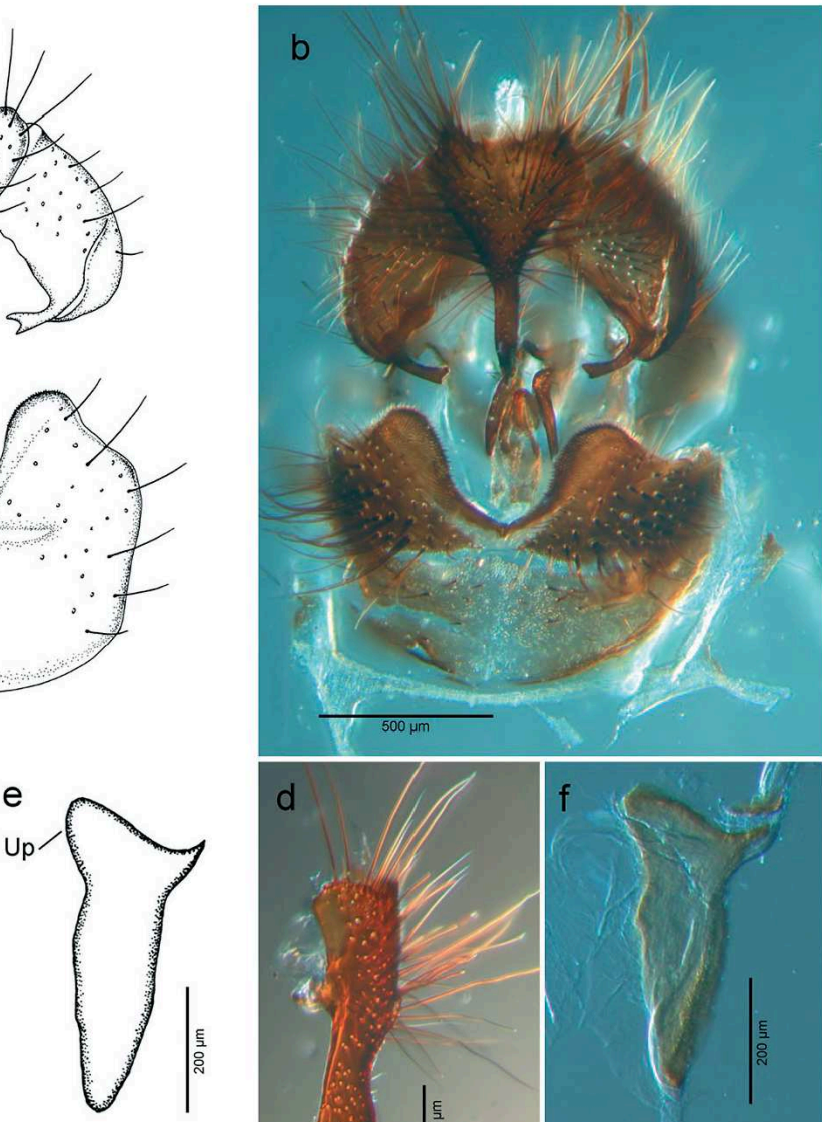

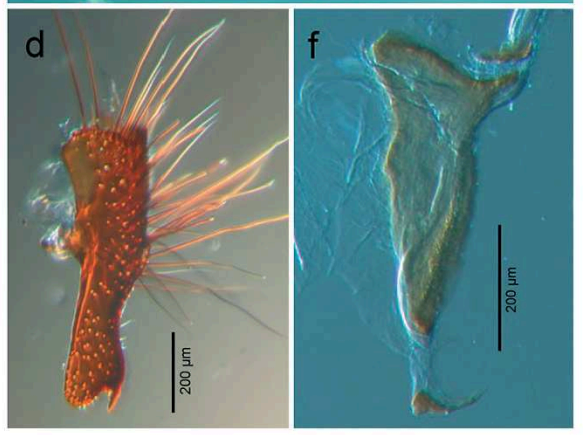

Fig 16. Tachina

(Echinogaster)

praeceps. $-\mathrm{a}, \mathrm{b}$.

Male postabdomen,

caudal view. $-\mathrm{c}, \mathrm{d}$.

Syncercus, lateral

view. $-\mathrm{e}, \mathrm{f}$.

Bacilliform sclerite.

Dph-distiphallus,

Sur-surstylus, Up-

upper projection. deep lateral (outer) incision gradually tapered towards tip, apical lobe relatively long and slender.

Bacilliform sclerite with upper projection slender, finger-like and rounded apically.

\subsubsection{T. (Tachina) magna (Giglio-Tos, 1890);} (Fig. 17)

Syncercus in caudal view slightly extending beyond apices of surstyli, in lateral view with the broader basal part separated from apical part by a deep emargination in dorsal margin, slender apical part with a slightly arched dorsal (outer) margin; ventral margin not distinctly incurved next to apical spine.

Surstylus in caudal view almost straight, incision of lateral (outer) margin at most slightly undulating; apical part subtriangular and singlepointed; distinctly extending below ventral margin of epandrium.
Bacilliform sclerite with an extended and transversely cut upper projection.

\subsubsection{T. (Servillia) lurida (Fabricius, 1781);} (Fig. 12)

Syncercus in caudal view distinctly constricted beyond middle, in lateral view with ventral margin concave in proximal half; dorsal margin strongly arched and somewhat abruptly tapered to middle; ventral margin of slender apical part distinctly emarginate immediately before the apical spine.

Surstylus in caudal view slightly undulating along lateral margin; apical subtriangular part moderately tapered towards tip, inner lobe only indicated.

Bacilliform sclerite with upper projection long, slender and sharply pointed. 

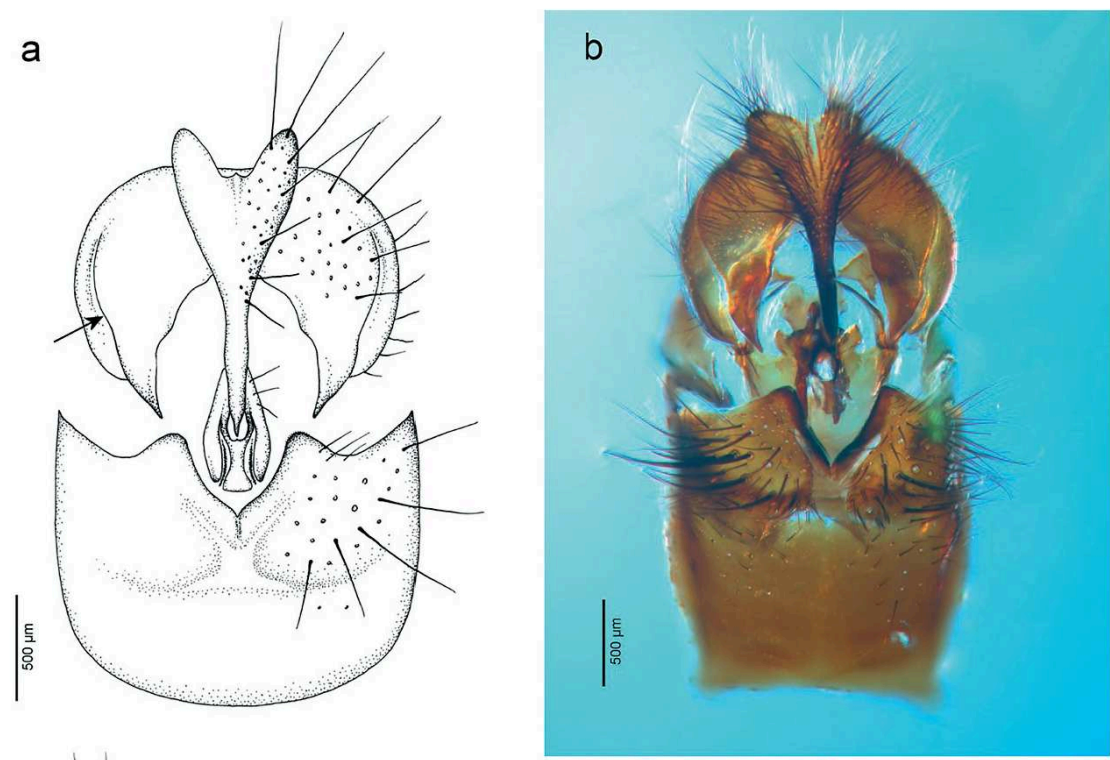

Fig 17. Tachina

(Tachina) magna.

$-a$, b. Male post-

abdomen, caudal

view. - c, d. Syn-

cercus, lateral view.

$-\mathrm{e}$, f. Bacilliform

sclerite.
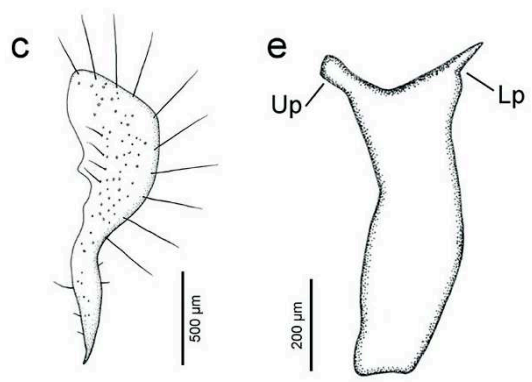

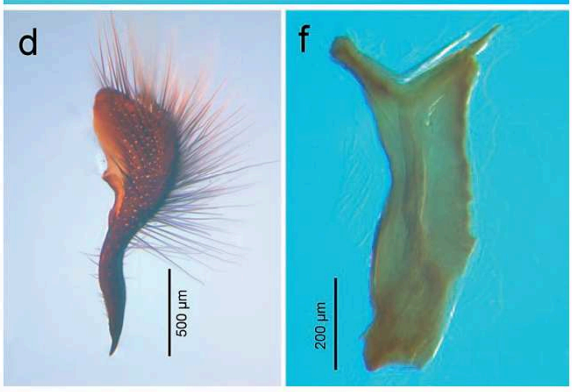

\subsubsection{T. (Servillia) nigrohirta (Stein, 1924);} (Fig. 13)

Syncercus in caudal view gradually tapered towards tip, not constricted beyond middle; in lateral view with dorsal margin not as abruptly incurved as in T. ursina but dorsal margin more concave beyond middle. However, the dorsal margin of the slender distal part is, contrary to both other species of subgenus Servillia, slightly convex; ventral margin not distinctly incurved immediately before apical spine, both ventral and dorsal margin gradually tapering towards the apical spine.

Surstylus in caudal view virtually without inner lobe; apical subtriangular part not markedly tapered towards tip as in T. ursina.

Bacilliform sclerite with upper projection almost subtriangular and much stouter than in T. lurida.
3.3.11. T. (Servillia) ursina Meigen, 1824; (Fig. 14)

Syncercus in caudal view gradually tapered towards tip, not constricted beyond middle; basal third in lateral view dilated and its ventral margin slightly concave; tapered distal part distinctly longer than in other species of subgenus Servillia; ventral margin not distinctly incurved immediately before the apical spine; apical spine relatively strong.

Surstylus in caudal view with a distinct submedial lobe; apical lobe with a conspicuously long and slender tip.

Bacilliform sclerite with pointed upper projections as in other species of subgenus Servillia.

\subsubsection{T. (Tachina) grossa (Linnaeus, 1758);} (Fig. 15)

See above characteristics of subgenus Tachina s.str. 
3.3.13. T. (Echinogaster) praeceps Meigen, 1824; (Fig. 16)

See above characteristics of subgenus Echinogaster.

\subsection{Identification key to males of West Palaearctic Tachina (incl. "Japanese" T. nupta)}

1. Apical lobe of surstylus straight and single pointed, not bent inwards (Figs 7-18a, b). Bacilliform sclerite with a slender upper projection, if relatively wide, then distinctly pointed (Figs 7-18e, f)

2

- Apical part of surstylus bent inwards, bifurcate or bicuspidate apically (Figs 15-16a, b). Bacilliform sclerite with a wide and rounded upper apical projection (Figs 15-16e, f) 13

2. Surstylus in caudal view with a lateral incision below middle; lateral margin angular or at least markedly undulating (Figs 4-11a, b). Syncercus in lateral view with a thick basal part that is longer than the tapered distal part (Figs 4-11c, d). Upper projection of bacilliform sclerite rounded (Figs 4-11e, f)

- Surstylus in caudal view without lateral incision (Figs 12-15a, b, 17a, b). This character seems to be partly problematic in some specimens of $T$. magna that do not distinctly differ from the Eudoromyia species. Syncercus in lateral view with a thick basal part that is hardly longer than the tapered distal part (Figs $17 \mathrm{c}, \mathrm{d})$. Upper projection of bacilliform sclerite obtuse (Figs 17e, f) or sharply pointed (Figs 12-14e, f)

3. Syncercus in caudal view with a callus laying in or beyond middle, visible as a distinctly swollen area provided with a more or less dense hair tuft, distal third of syncercus relatively stout (Figs 4-5a, b, 7a, b, 11a, b); in lateral view with the medial callus more or less distinct, distal third tapering towards the apical spine (Figs 4-5c, d, 7c, d, 11c, d)

- Syncercus without a callus; distal third in caudal view conspicuously slender (Figs 6a, b, 8$10 \mathrm{a}, \mathrm{b})$, in lateral view either with dorsal and ventral margins almost parallel (Figs 6c, d, 9$10 \mathrm{c}, \mathrm{d})$ or with dorsal margin slightly convex
(Figs 8c, d)

4. Syncercus in lateral view distinctly swollen below middle and concave at beginning of slender apical part (Figs 4c, 7c)

5

- Syncercus in lateral view not swollen below middle and barely concave at beginning of slender apical part (Figs 5c, 11c)

6

5. Callus in distal half of syncercus conspicuous in caudal as well as in lateral view (Figs 4a, d)

T. (Eudoromyia) canariensis

- Callus in distal half of syncercus less conspicuous (Figs 7a,c) T. (Eudoromyia) fera

6. Apical lobe of surstylus stout, with short tip (Fig. 5a)

T. (Eudoromyia) casta

- Apical lobe of surstylus slender, with a long tip (Fig. 11)

T. (Eudoromyia) sp.

7. Apical lobe of surstylus stout and with a short tip (Figs 9a, b) (central Europe)

T. (Eudoromyia) nupta

- Apical lobe of surstylus somewhat more slender and with an elongated tip (Figs 6a, b, 8a, b, $10 \mathrm{a}, \mathrm{b})$

8

8. Syncercus in lateral view with dorsal margin almost straight in about distal half, not distinctly concave beyond middle (Figs 6c,d). Upper projections of bacilliform sclerite relatively stout (Figs 6e, f)

T. (Eudoromyia) corsicana

- Syncercus in lateral view with dorsal margin distinctly concave beyond middle (in distal third) (Figs 8c, d, 10c, d). Upper projections of bacilliform sclerite relatively slender (Figs $8 \mathrm{e}, \mathrm{f}, 10 \mathrm{e}, \mathrm{f})$

9. Outer (dorsal) margin of syncercus in lateral view almost straight in distal half; relatively broad in basal half (Figs 10c, d). Bacilliform sclerite with upper and lower distal projections separated by a shallow emargination (Figs 10e, f) (Japan) T. (Eudoromyia) nupta

- Syncercus in lateral view with dorsal margin slightly convex in distal half; relatively slender in basal half (Figs 8c, d). Bacilliform sclerite with upper and lower distal projections separated by deep emargination (Figs 8e, f) T. (Eudoromyia) magnicornis

10. Hypopygium in caudal view with surstylus markedly extending below lower margin of epandrium (Figs 17a, b). Upper projection of bacilliform sclerite straight and obtuse (Figs $17 \mathrm{e}, \mathrm{f})$

T. (Tachina) magna 


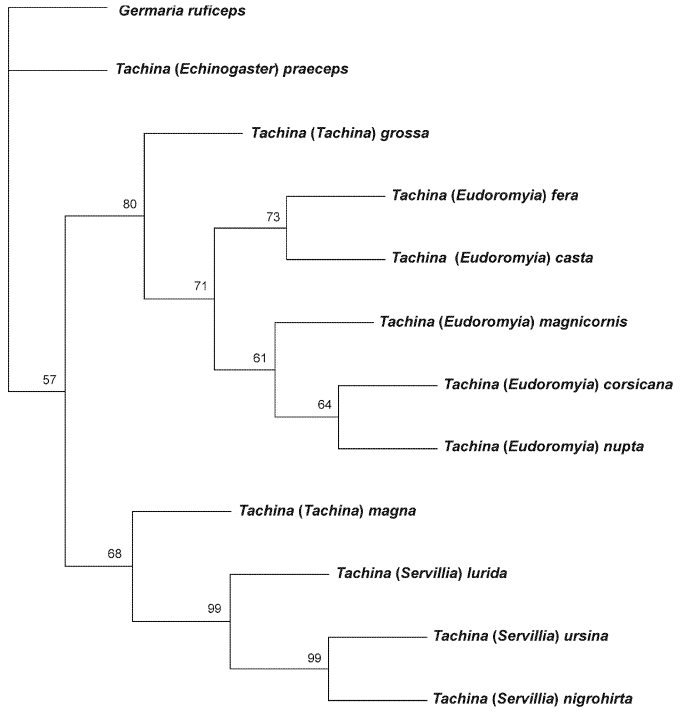

100 changes/site

Fig. 18. Phylogenetic tree based on the combined analysis of four mitochondrial DNA markers (CO I, Cyt b, $12 \mathrm{~S}$ and $16 \mathrm{~S}$ rDNA) of total length of $1495 \mathrm{bp}$ for subgenera resolution. New proposed subgenus for $T$. magna would be a sister group of subgenus Servillia and T. praeceps from subgenus Echinogaster as a basal line of the genus Tachina close to original subgenus Tachina s.str.

- Hypopygium in caudal view with surstylus not or insignificantly extending below lower margin of epandrium (Figs 12-14a, b). Upper projection of bacilliform sclerite sharply pointed (Figs 12-14e, f)

11. Syncercus in lateral view with ventral margin abruptly incurved next to apical spine; dorsal and ventral margins almost parallel from middle to apical spine (Figs 12c, d)

\section{T. (Servillia) lurida}

- Syncercus in lateral view with ventral margin at most only slightly incurved next to apical spine; dorsal and ventral margins more or less tapering distally (Figs 13-14c)

12. Apical lobe of surstylus in caudal view with a subtriangular and stouter tip than in the following species (Figs 13a, b). Dorsal margin of syncercus distinctly concave beyond middle (Figs 13c, d) T. (Servillia) nigrohirta

- Apical lobe of surstylus in caudal view with a long and pointed tip (Figs 14a, b). Dorsal margin of syncercus barely concave beyond middle (Figs 14, d)

T. (Servillia) ursina
13. Hypopygium in caudal view higher than wide. Syncercus distinctly extending below level of surstyli. Surstylus in caudal view with a well-defined lobe on medial margin (Fig. 15a)

T. (Tachina) grossa

- Hypopygium in caudal view low and wide. Syncercus not extending below level of surstyli. Surstylus in caudal view without a lobe on medial margin (Fig. 16a)

T. (Echinogaster) praeceps

\subsection{Molecular analyses of the subgenera and species levels}

The resulting tree obtained by Bayesian analyses has been used here for validation of the position of subgenera within the genus Tachina (Fig. 18). The resolution of the tree is good and the reliabil-

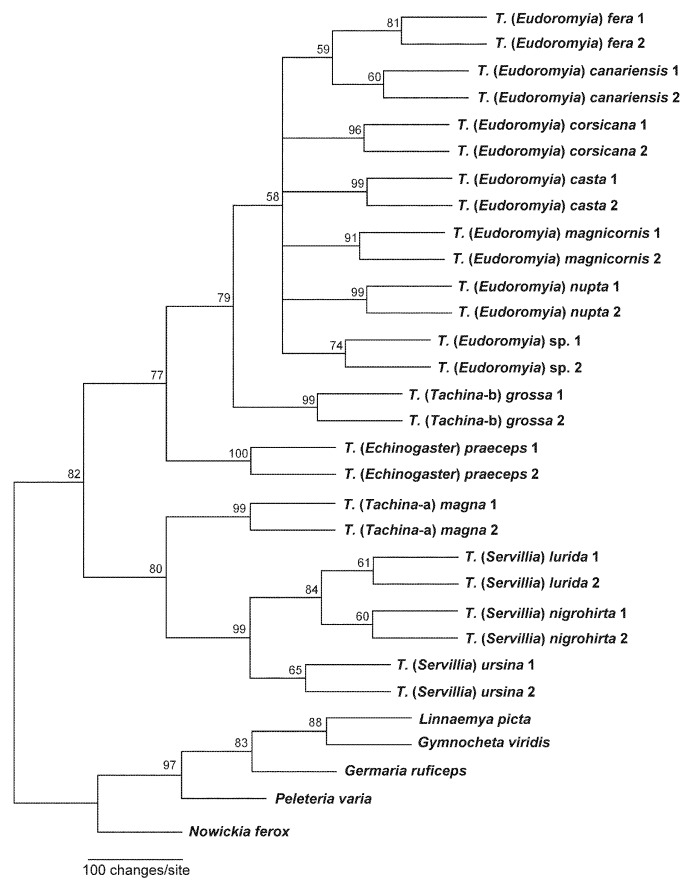

Fig. 19. Phylogenetic tree based on combined molecular (12S, 16S rDNA) and morphological analyses of postabdominal characters. The $50 \%$ majority-rule consensus tree of the 31 most parsimonious trees obtained (tree length $=310, \mathrm{Cl}$ excluding uninformative characters $=0.5625, \mathrm{HI}$ excluding uninformative characters $=0.4375$, retention index $(\mathrm{RI})=0.7640$, rescaled consistency index $(R C)=0.5053)$. - Only Japanese specimens of $T$. nupta included. 
Table 3. Matrix of the male postabdomen characters and their states used in the cladistic analysis.

Male postabdomen characters:

$\begin{array}{lllllllllllll}\text { Tachina subgenera: } & 1 & 2 & 3 & 4 & 5 & 6 & 7 & 8 & 9 & 10 & 11\end{array}$

\section{(Eudoromyia)} canariensis

casta

corsicana

fera

magnicornis

nupta

sp.

(Tachina)

magna

(Servillia)

lurida

nigrohirta

ursina

(Tachina)

grossa

(Echinogaster)

praeceps

Outgroups

\section{Tachinidae}

Germaria ruficeps

Gonia divisa

Gymnocheta viridis

Linnaemya picta

Nowickia ferox

Peleteria rubescens

Schineria tergestina

Winthemia variegata

Rhinophoridae

Stevenia atramentaria

$\begin{array}{llll}1 & 1 & 1 & 0 \\ 1 & 1 & 1 & 0 \\ 1 & 1 & 1 & 0 \\ 1 & 1 & 1 & 0 \\ 1 & 1 & 1 & 0 \\ 1 & 1 & 1 & 0 \\ 1 & 1 & 1 & 0\end{array}$

$\begin{array}{lllllll}1 & 2 & 0 & 1 & 0 & 2 & 1 \\ 1 & 2 & 0 & 1 & 0 & 2 & 1 \\ 0 & 2 & 0 & 1 & 0 & 2 & 1 \\ 1 & 2 & 0 & 1 & 0 & 2 & 1 \\ 0 & 2 & 0 & 1 & 0 & 2 & 1 \\ 0 & 2 & 0 & 1 & 0 & 2 & 1 \\ 1 & 2 & 0 & 1 & 0 & 2 & 1\end{array}$

1
1
1
1

$\begin{array}{lll}1 & 1 & 1 \\ 1 & 1 & 1\end{array}$

0

0

20

200

2

0
0

0

0

3

1

1

02

0

$\begin{array}{ll}3 & 1 \\ 3 & 1\end{array}$

$\begin{array}{lllllll}0 & 2 & 2 & 0 & 1 & 1 & 1\end{array}$

$\begin{array}{llll}1 & 1 & 1 & 0 \\ 1 & 1 & 1 & 0\end{array}$

0

$2 \quad 2$

0

$1 \quad 1 \quad 1$

States of characters:

1: Postabdomen: $\mathbf{0}$-non capsular; 1-capsular.

2: Cerci: 0-not completely fused medially; 1-completely fused medially forming a syncercus.

3: Termination of syncercus: 0 -blunt; 1 -with spine.

4: Syncercus (cerci) laterally: 0-broad proximal part longer than narrow distal part or both parts only slightly different and separated at most by a shallow emargination; 1-broad proximal part shorter or separated from distal part by a deep emargination of dorsal margin.

5: Medial or submedial callus (dilation) on syncercus: 0-not visible in caudal view, 1-visible in caudal view.

6: Connection of surstylus and epandrium: $\mathbf{0}$-membranous; 1 -with short flexible fusion (surstylus often divided transversely into 2 sclerites); 2-strong immovable fusion (surstylus not divided).

7: Surstylus: 0-straight; 1-slightly curved towards syncercus; 2 -distinctly incurved towards syncercus.

8: Surstylus: 0-without distinct outer incision; 1-with distinct outer incision.

9: Apex of surstylus: 0 -simple; 1 -divided into two small lobes (bicuspidate).

10: Bacilliform sclerite: 0-straight, rod-like; 1-extended and with upper distal projection short and rounded; $2-$ extended and with upper distal projection long and rounded apically; 3 -extended and with upper distal projection long and pointed or cut transverselly.

11: Epiphallus: $\mathbf{0}-$ well developed, situated medially; $1-$ reduced.

ity of branches is high. The tree forms three main branches according to known subgenera: Echinogaster (1 sp.), Servillia (3 spp.) and Eudoromyia (7 spp.). Subgenus Eudoromyia is divided into two subgroups, the $T$. fera group and the $T$. magnicornis group (see below). The separate position of $T$. gross $a$ is confirmed here, it is closer to the subgenera Echinogaster or Eudoromyia than to $T$. magna, which is treated in subgenus $T a$ china s.str. now. T. magna is distinctly separated and more related to subgenus Servillia than to $T$. grossa.

The phylogram in Fig. 19 shows the results of the combined molecular (12S, 16S rDNA) and 
morphological characters (11 characters from the male postabdomen, see Table 3 ). Of the total 688 combined characters 110 were parsimony-informative. In the analysis we obtained 31 most parsimonious trees of which a $50 \%$ majority rule consensus tree was performed. The combined molecular-morphological analysis also well defined the subgroups inside Tachina, including all species under analysis. The validity of the tree (Fig. 19) is also demonstrated by the fact that both specimens analyzed from each species are located on the identical position.

\section{Discussion}

\subsection{Postabdominal characters studied}

\subsubsection{General form of postabdomen}

The spherical epandrium was only observed in the species ascribed to the former subtribe/tribe Tachinina/Tachinini (sensu Mesnil 1966 and Herting 1984) (character 1, Table 3: state 1,). This fact is also discussed by Tschorsnig (1985), who named such postabdomen as capsular and regarded it as a synapomorphy in Tachinina.

\subsubsection{Cerci or syncercus}

Separated (not fused) cerci are known e.g. in Rhinophoridae and cerci fused in a syncercus represent a derived state (character 2, Table 3: state 1). This interpretation was also shared by Tschorsnig (1985), who considered non-fused cerci to be a character in the ground plan of Calyptratae.

\subsubsection{Termination of syncercus}

A syncercus with a distinct apical spine as in Tachina (character 3, Table 3: state 1) is considered here, supported by numerous illustrations (Zimin et al. 1970, Zimin \& Kolomietz 1984, Tschorsnig 1985, Chao et al. 1998), to represent a derived state, which was proved in Tachina and Schineria.

\subsubsection{Syncercus laterally}

Tschorsnig (1985) described the functional importance of the syncercus during copulation for fixing the female genitalia in the optimal position and Mesnil (1966) repeatedly expressed the taxonomic significance of the shape of the syncercus in Tachina. Two discrete character states are recognized here (depending on the relation between the wide basal and more slender distal part) and one of them was also found in outgroups (character 4, Table 3).

\subsubsection{Callus on syncercus}

A syncercus with a medially or submedially dilated callus was only found in some species of subgenus Eudoromyia ( $T$. canariensis, $T$. casta, T. fera, and T. sp.) (character 5, Table 3: state 1). The presence of this character may indicate a different complex character of the syncercus.

\subsubsection{Connection of surstylus with epandrium}

A flexible connection of surstyli and epandrium through a narrow membrane, easily recognizable in most Calliphoridae, Rhinophoridae and Sarcophagidae, may be interpreted as a plesiomorphic character state. A fixed immovable connection (Tschorsnig 1985) (between basal plate of surstylus and epandrium) as observed in Tachina, is apparently a synapomorphy for some closely related genera within the Tachinini group (of these most relative groups inside tribe Tachinini) (character 6, Table 3: state 2). An intermediary state was described by Tschorsnig (1985) and constitutes a connection between epandrium and the base of surstylus by means of a small sclerotized bridge (character 6, Table 3: state 1).

\subsubsection{Surstylus a (character 7 in Table 3)}

Tachi \& Shima (2006a) stated that a straight surstylus represents a plesiomorphic character state and a surstylus bent inwards towards syncercus represents an apomorphic state. Tschorsnig (1985) considered this character as significant though he did not polarize both states. We recognize thus a surstylus with the apical lobe 
distinctly hairy and more or less subtriangular (character 7, Table 3: state 0) and a hook-like surstylus directed towards syncercus. (character 7 , Table 3: state 1 and 2).

\subsubsection{Surstylus b (character 8 in Table 3)}

The absence (state 0 ) or presence (state 1) of a distinct lateral incision is here considered to constitute a complex structural character. Based on study of model outgroups and also through comparison with data and drawings in previous publications (Tschorsnig 1985, Chao et al. 1998, Tachi \& Shima 2005, 2006a, 2006b, etc.) it is stated that the lateral incision is a unique state, i.e. it represents a synapomorphy of the subgenus Eudoromyia.

\subsubsection{Apex of surstylus}

A bicuspidate apex of surstylus, i.e. apex ending with two small lobes (character 9, Table 3: st. 1) is a complex structure, found in some species of subtribus Tachinina (sensu Mesnil 1966 and Herting 1984) in contrast to the majority of the species examined.

\subsubsection{Bacilliform sclerite}

Tschorsnig (1985) noted that a rod-like sclerite is original, occurring in most Calliphoridae and Tachinidae but also in Muscidae and Anthomyiidae. In some Tachinidae and very often in subfamily Tachininae, this sclerite is expanded, more or less plate-like and regarded as a derived state by Tschorsnig (1.c.). In Tachina the apomorphic state of this character may be separated into 3 different forms $(0-$ straight, rod-like; 1 extended and with upper distal projection short and rounded; 2 - extended and with upper distal projection long and rounded apically; 3 - extended and with upper distal projection long and pointed or cut transversely) and its significance for any analysis seems to be indisputable (character 10, Table 3: st. 1-3).

\subsubsection{Epiphallus}

The presence of a long epiphallus in dorsobasal position represents the original state (Tschorsnig
1985). A complete reduction as known in the Tachinini represents a derived state (character 12, Table 3: st. 1).

\subsection{Characters not used in analysis}

\subsubsection{Lobes of sternite 5}

Posteromedial lobes bordering the posterior median incision of sternite 5 may be developed, across genus Tachina, as discrete states: $0-$ rounded and not very prominent or 1 - more or less tapered or pointed. Nevertheless, a study of a large array of outgroups proved that the distribution of both states does not support any grouping of related taxa.

\subsubsection{Length of syncercus and height of epandrium}

This character depends on different combinations of various mutually independent processes (reduction, extension, compression etc.) e.g., flattening that markedly reduces the height of the epandrium can result that even a very short syncercus may overlap its ventral margin. A criterion of homologization of this structure is hence barely possible. Nevertheless, this character may be used for distinguishing some species between and within certain subgenera (cf. e.g. T. praeceps and T. magnicornis).

\subsubsection{Fixation of syncercus \\ to epandrium (= tergite 9 )}

In some species of Tachina (e.g. T. casta, T. canariensis, $T$. fera, $T$. grossa, $T$. magnicornis, $T$. praeceps and T. ursina) there are hook-like projections of the epandrium directed towards the basal part of the syncercus, enabling a membranous articulation with the epandrium. However, such epandrial projections do not appear to be rare in Tachininae, appearing e.g. in Gymnocheta viridis, Germaria ruficeps and Nowickia ferox. Apparently this character developed several times. 


\subsubsection{Pregonite apex shape}

This character (apex bent or rounded) is probably trivial and has originated independently several times throughout the Tachinidae. It is thus not suitable for an analysis.

\subsubsection{Postgonite shape}

According to our studies and published data (Verbeke 1962, Tschorsnig 1985) a wide spectrum of the postgonite shape is known, indicating a complicated phylogeny. This character is thus preliminarily removed out of the analysis.

\subsubsection{Type of surstylus}

In Tachina there are two states of shape: $0-$ surstylus with a slender distal part and 1 surstylus with a short subtriangular apical lobe. The second state varies considerably not only within Tachina (including its subgenera) but also in Calliphoridae, Rhinophoridae and Miltogrammatinae (Sarcophagidae) (Tschorsnig 1985). The different forms of the apical part of the surstylus have most probably originated independently several times.

\subsubsection{Length of surstylus \\ compared with length of syncercus}

In Tachina there are three states known: $0-$ length of surstylus and syncercus equal, 1 surstylus shorter than syncercus, 2 - surstylus longer than syncercus. Tachi \& Shima (2006a) used relative length of surstylus in their analysis of Phorinia Robineau-Desvoidy 1830 . The equal length is probably representing the original state found also in Calliphoridae, Rhinophoridae and Miltogrammatinae (Sarcophagidae). However, it seems to be problematic to determine a discrete state of this character because it depends, e.g., on the relative length of the surstylus or the extent of its bending, on the position of the point of fixation to the epandrium, etc. Moreover, in the Tachina species examined the syncercus is always extends beyond the apex of surstylus in lateral view.

\subsubsection{Fusion of hypandrial arms}

In Tachina the arms of the hypandrium are separated as in Calliphoridae, Sarcophagidae and Rhinophoridae (Tschorsnig 1985). A derived state at the species level is a fusion of both arms (Tachi \& Shima 2006a). In such a case the separated arms of the hypandrium may be designated as a symplesiomorphy. Griffiths (1972), however, supposed at the family level of Cyclorrhapha that the fusion represents the plesiomorphic character state and a separation of hypandrial arms a derived state. It cannot be ruled out that a fusion has appeared in different phyletic lines independently.

\subsubsection{Microstructure of membranous part of distiphallus}

Verbeke (1962) considered the macro- and microstructure of the distiphallus to constitute very important characters in the male terminalia of tachinids. Following his conclusion, presence or absence of the ventral and lateral distiphallus microstructure is the main criterion for recognition of the distiphallus types. A distinct apomorphic state, i.e. lateral microstructure of distiphallus with a longitudinal band of pigmented denticles, is found in the subgenus Servillia and also in T. magna (character 11, Table 3: state 1).

\subsection{Relationships among the taxa examined}

\subsubsection{Phylogeny of the genus Tachina}

According to the male postabdominal structures and cladistics based on them (Fig. 20) a model group of the Tachinina/Tachinini (cf. Mesnil 1966, Herting 1984) (Peleteria, Nowickia, Schineria and Tachina) forms a monophylum based on capsular postabdomen (character 1, Table 3) and a reduced epiphallus (character 12, Table 3). But West Palaearctic Tachina spp. indicate a possible paraphylum with Schineria which is a part of the Tachina cladistic branch (Fig. 20). Synapomorphies for both Tachina - Schineria are the presence of apical spine of syncercus (character 3, Table 3) and strong immovable fusion of surstyli with epandrium (character 6 , 


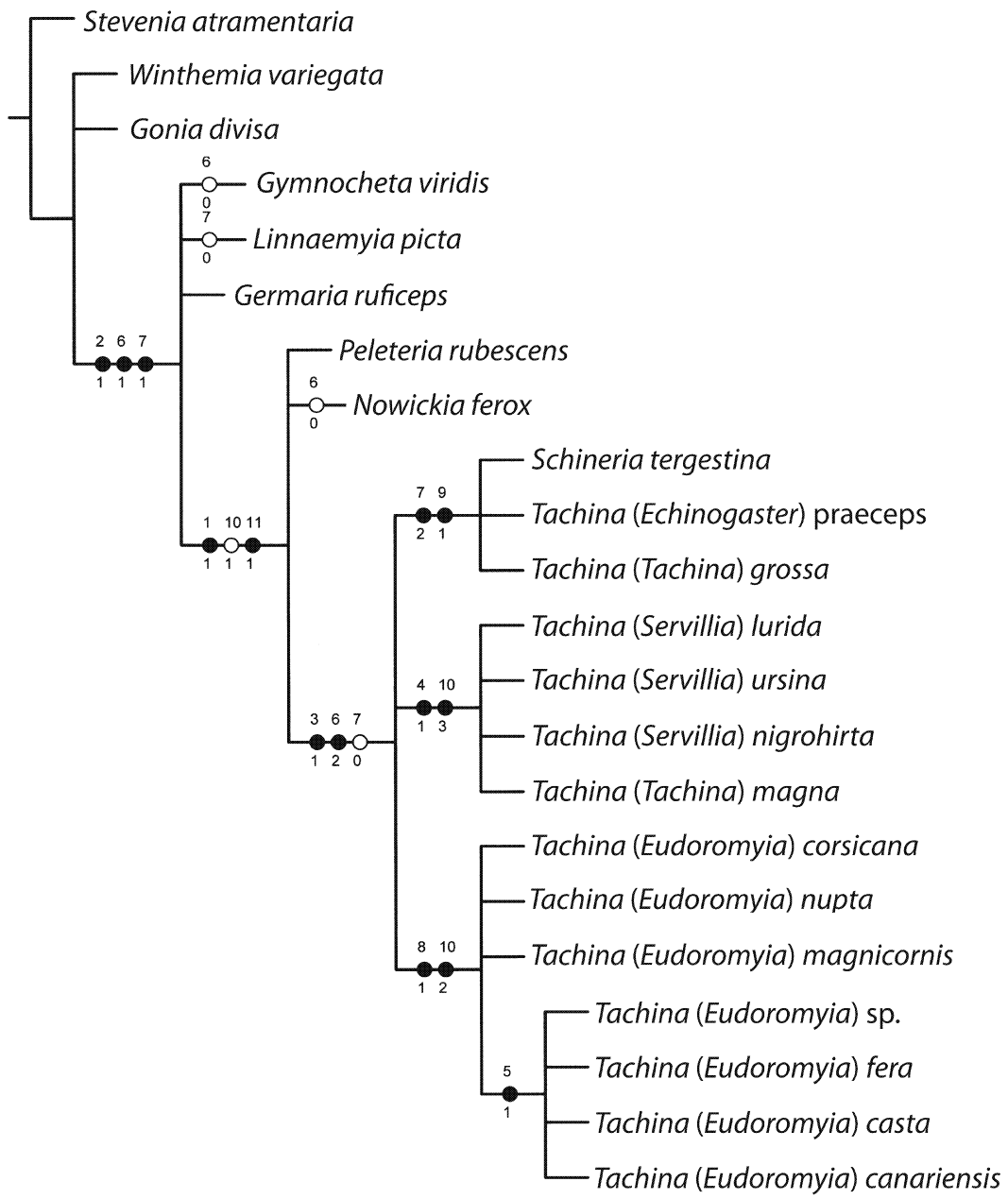

Fig. 20. Cladistic analysis based on male postabdominal characters with strict consensus of 9 trees and parameters; matrix see Table 3.

\section{-: homology,} O: homoplasy; number above: number of characters, number below: state of character.
Table 3). Unfortunately this information could not been validated by analysis of its DNA as the taxon Schineria is rare and no specimens suitable for this analysis were obtained.

Inside Tachina - Schineria there are three subgroups (Fig. 20).

a) Tachina grossa, T. praeceps and Schineria tergestina, with surstyli distinctly incurved towards syncercus (character 7, Table 3) and apex divided into two small lobes (bicuspidate) (character 9, Table 3).

b) subgenus Servillia with T. magna form a separate group based on the similar shape of the syncercus: -a relation between its proximal and distal parts (character 4, Table 3), -the form of bacilliform sclerites which are extended and with their upper distal projections being long and pointed or cut transversely (character 10, Table
3), -with the distiphallus with intensively pigmented microdenticles along lateral membrane (character 11, Table 3).

c) subgenus Eudoromyia with distinct outer incision of surstylus (character 8, Table 3 ) and with extended bacilliform sclerites showing distal projections long and rounded apically (character 10, Table 3). Inside Eudoromyia $T$. fera, $T$. casta, and $T$. canariensis form a subgroup with distinct callus on syncercus (character 5, Table 3 ). This cluster is clearly exhibited in both molecular analyses (Figs 18-19).

\subsubsection{Taxonomic value}

of the postabdominal characters

Many of the male terminalia structures developed in tachinids independently several times (cf. 
Tschorsnig 1985) and this fact is also reflected in the characteristics of Tachina species as in many other genera of Tachinidae. On the other hand, some structures described in the framework of the male terminalia provide relatively reliable differences at the subgeneric as well as species level. The most typical common character for the species of Tachina is the apical spine of the syncercus (but it was also found in Schineria). The fusion of the cerci to a syncercus is not a character specific to this group as it is widely distributed. The shape of the pregonite and postgonite appears to be typical for the genus Tachina, but is shared with Schineria and Peleteria. The surstylus being partly fused with the epandrium as well as narrow, convergent and not fused hypandrial arms are virtually the same in Schineria and Peleteria and a plate-like bacilliform sclerite is also known in these genera. For all of them also a reduction of tergite 6 and a complete reduction of the epiphallus are characteristic. The asymmetry of sternite 6 found in Tachina belongs undoubtedly to the fundamental structural plan of the whole Cyclorrhapha. Likewise segment 7 seems to be very basal with its apophyse on the right side (cf. Tschorsnig 1985: 95).

\subsubsection{Position of the present subgenus Tachina s.str.}

A subdivision of Tachina into four subgenera was accepted, is based on parallel morphological and molecular analyses (Figs 4-6) and also polyphasic approach by Muráriková et al. (in press). But a potential new subgenus is recommended for $T$. magna, which is not closely related to $T$. grossa. T. magna has recently been everywhere treated as belonging to subgenus Tachina s.str., together with the type species $T$. grossa of the subgenus. However, results of the analysis of male postabdominal structures, cladistics and two significant and independent molecular analyses confirmed a hypothesis that T. magna is much more related to the species of subgenus Servillia than to $T$. grossa and its placement into subgenus Tachina s.str. seems to be problematic.

Differences between both included species in the shape of epandrium, syncercus, surstylus, and bacilliform sclerite are distinctly greater than characters of only a specific level within the other subgenera. Also the position of both species in the phylogenetic trees (Fig. 20) and the identification key proves that these species hardly belong to the same subgenus.

Concerning the inter- and intra-subgeneric relationships based on molecular analyses, the phylogram based on 4 markers (Fig. 18) resolves much better relationships within the subgenus Eudoromyia. In Fig. 19 (2 markers + morphology) the fera-canariensis branch is the only resolved clade within Eudoromyia. The sister position of the subgenus Tachina, represented by $T$. grossa to subgenus Eudoromyia is obvious and wellsupported in both trees. The same situation exists in the relationship of the subgenus Servillia and the species T. magna, which is in all presented phylograms obviously a sister-relationship. This position of T. magna excludes it from the subgenus Tachina and is in full correspondence with the cladistic analysis as well. The branch covering the subgenus Servillia shows strong support in both analyses. The position of the subgenus Echinogaster shows a slight incongruity. In the four-marker analysis it represents the basal branch in sister position to all other subgenera and on the other hand in two-marker analysis combined with morphological features shows a basal sister position only to the Tachina + Eudoromyia clade.

On the basis of the obtained results, the future establishment of a new subgenus for T. magna appears to be the best solution of this problem. Both analyses of the present paper (four markers vs. two markers+morphology) support the potential establishment of a new subgenus which shows a sister relationship to the subgenus Servillia.

A new subgenus is not formally established here because a worldwide revision (including a holomorphological study of all available characters, i.e. outer morphology, male and female postabdomina, eggs, larvae, development, ecology) of the species of Tachina appears to be a necessary prerequisite.

\subsubsection{Potential new species found}

Among the specimens examined of the subgenus Eudoromyia an additional species (cf. Fig. 11) was delimited which undoubtedly belongs to the 
T. fera species group (T. fera, $T$. canariensis, $T$. casta) characterized by the distinct callus on the syncercus. It differs in male genital characters from $T$. canariensis and $T$. casta by the relatively long syncercus and from $T$. fera by the extent of the callus on the syncercus and the shape of the bacilliform sclerite. For external morphological differences to other species of Tachina see Tschorsnig et al. (2003: 30). This evidently new boreo-alpine species recorded from Sweden, Finland, French Alps and Slovakia is not formally described here because the actual identity of some other European species is not clear and a study of their type specimens appears to be necessary. The molecular support of the potentially new Eudoromyia species is evident. However, its position within the subgenus based on the maximum parsimony analysis is unclear.

\subsubsection{Restoring T. nigrohirta (Stein, 1924) from synonymy}

The material which was treated in the present paper as $T$. nigrohirta is in all analyses clearly separated from the other two Servillia species. About its validity there is no doubt. However, its position and relationship to the other two species slightly differs in both phylograms. While using morphology characters only, the relationships within the subgenus are not resolved. Adding two mitochondrial markers moves $T$. nigrohirta to the sister-relationship with $T$. lurida. This position is slightly confusing, as $T$. nigrohirta was regarded as a synonym of $T$. ursina. The four-marker analysis finally places $T$. nigrohirta to the sister-position with $T$. ursina. It is an interesting observation, that the combined "molecular-morphology" analysis did not cluster this species with T. ursina despite their morphological resemblance.

\subsubsection{Differences inside populations of T. nupta (Rondani, 1859)}

The correctness of former identifications of West Palaearctic T. nupta is apparently problematic to evaluate (cf. also Tschorsnig \& Herting 1994) and the re-examination of specimens previously assigned to T. nupta often led in this study to different species of subgenus Eudoromyia. This problem was already mentioned in an earlier study, where incorrect identification of this species was confirmed by a mathematical method (by Artificial Neural Networks, see Vaňhara et al. 2007). Mesnil (1966) recognized two subspecies, i.e. the West Palaearctic or South European T. nupta Rondani, 1859 and the East Palaearctic T. nupta micado (Kirby, 1884) but both these taxa were later synonymized by Herting (1984). In our attempt to elucidate if the present $T$. nupta hides one or two species, a limited material was available and the results could be influenced by this fact.

But also O'Hara et al. (2009) mentioned a possibility of such species complex. Nevertheless, the tree based on the DNA analysis of $T$. nupta from Japan is consistent and results obtained in contrast to West Palaearctic specimens are convincing. But it is evident that more material is needed for DNA analysis, which should be widely tested also by further taxonomic tools. The last case (and also all previous taxonomic solutions) was also separately successfully processed by the tool of artificial intelligence (Artificial Neural Networks, see Muráriková et al. in press).

\section{Conclusions}

One of the main goals of this study was to find suitable characters confirming the conclusions of the molecular analyses. Such characters are fundamental for distinguishing of species with the help of an identification key based on morphological characters. It is not surprising that at least in some cases (Eudoromyia subgenus) our proposals need a further study.

- Characters of the male terminalia were found as important in an attempt to solve existing taxonomical problems in Tachina.

- For some species i.e. T. canariensis, T. casta and $T$. corsicana we present original pen drawings and micrographs which are the first illustrations of the structure of their male terminalia.

- The molecular analyses up to four mitochondrial markers (CO I, Cyt b, 12S and $16 \mathrm{~S}$ rDNA), also combined with cladistics based on the male postabdominal characters were 
used to support the taxonomic analyses and recommendations. All results mentioned were verified quite independently by this decisive method.

- A subdivision of Tachina to four subgenera was therefore accepted, but a potential new subgenus is recommended for $T$. magna which is not closely related to $T$. gross $a$ and its placement in the subgenus Tachina s.str. seems to be problematic.

- An expected (presumably new) species, here preliminarily treated as $T$. (Eudoromyia) sp., is besides external morphology also based on discrete structures of the male terminalia and its position was also supported by the DNA analysis. A formal description needs a revision of type specimens of several described species (which, however, could also lead to the result that there is already a name available for it).

- The subgenus Eudoromyia may be divided into two species groups i.e $T$. fera species group which includes $T$. fera, $T$. canariensis, $T$. casta and $T$. sp. and T. magnicornis species group with T. magnicornis, $T$. corsicana and T. nupta.

- It is also confirmed, based on characters of male terminalia and molecular-genetic analysis, that it is correct to remove $T$. nigrohirta from the synonymy with $T$. ursina.

- Central European T. nupta differs from what is treated in the present paper as T. nupta from Japan. Our analyses show that the Japanese specimens form a homogeneous taxon. The present status of West Palaearctic T. nupta is, however, as yet unsolved, due to the unclear situation of type-material and the insufficient morphological description of the species; it should be revised in detail.

Acknowledgements. For financial support, the Ministry of Education of the Czech Republic and the Masaryk University (grant No. MSM 0021622416) and Research Fellowship of the Czech Science Foundation (GAČR 524/05/ H536) are acknowledged. For kind loans or gifts of Tachina material we are obliged to M. Barták, C. Bergström, P. Cerretti, S. Čepelák, R.T. Ichiki, H.-P. Tschorsnig, and J. Ziegler. Last, but not least our thanks are also extended to C. Bergström, H.-P. Tschorsnig, I. Malenovský, and J. O'Hara for their valuable discussions and taxonomic advices and to P. J. Chandler for linguistic cooperation.

\section{References}

Augustí, N., Bourget, D., Spataro, T., Delos, M., Eychenne, N., Folcher, L. \& Arditi, R. 2005: Detection, identification and geographical distribution of European corn borer larval parasitoids using molecular markers. - Molecular Ecology 14: 3267-3274.

Chao, C.-M., Shi, Y.-S., Zhou, S.-X., Chen, R.-J., Liang E.-Y, \& Sun, X.-K. 1998: Tachinidae. - In: Xue, W.Q. \& Chao, C.-M. (eds.), Flies of China. Volume 2: 1661-2206. Liaoning Science and Technology Press, Shenyang. 2425 pp. [In Chinese.]

Cook, C. E., Austin, J. J. \& Disney, R. H. L. 2004: A mitochondrial $12 \mathrm{~S}$ and $16 \mathrm{~S}$ rRNA phylogeny of critical genera of the Phoridae (Diptera) and related families of Aschiza. - Zootaxa 593: 1-11.

Flook, P. K. \& Rowell, C. H. F. 1997: The effectiveness of mitochondrial rRNA gene sequences for the reconstruction of the phylogeny of an insect order (Orthoptera). - Molecular Phylogenetics and Evolution 8: 177-192.

Gariepy, T. D., Kuhlmann, U., Gillott, C. \& Erlandson, M. 2007: Parasitoids, predators and PCR: the use of diagnostic molecular markers in biological control of Arthropods. - Journal of Applied Entomology 131: 225-240.

Goloboff, P. 1993: NONA, version 2.0. — Published by the author. [www document]. URL http:/www.cladistic.com. (Site visited on March 2008)

Griffiths, G.C. D. 1972: The phylogenetic classification of Diptera Cyclorrhapha with special reference to the structure of the male postabdomen. - Series entomologica 8, W. Junk, The Hague. 340 pp.

Guryev, V., Makarevitch, I., Blinov, A. \& Martin, J. 2001: Phylogeny of the genus Chironomus (Diptera) inferred of mitochondrial cytochrome B and cytochrome oxidase I. - Molecular Phylogenetics and Evolution 19: 9-21.

Herting, B. 1984: Catalogue of Palaearctic Tachinidae (Diptera). - Stuttgarter Beiträge zur Naturkunde, Serie A, (Biologie) 369. 228 pp.

Herting, B. \& Dely-Draskovits, Á. 1993: Tachinidae. In: Soós, Á \& Papp, L. (eds.), Catalogue of Palaearctic Diptera. Vol. 13 Anthomyidae-Tachinidae: 118-624. Hungarian Natural History Museum, Budapest. 624 pp.

Huelsenbeck, J. P. \& Ronquist, F. R. 2001: MrBayes: Bayesian inference of phylogeny. - Biometrics 17: 754 755.

Krzywinski, J., Wilkerson, R. C. \& Besansky, N. J. 2001: Evolution of mitochondrial and ribosomal gene sequences in Anophelinae (Diptera: Culicidae): Implications for phylogeny reconstruction. - Molecular Phylogenetics and Evolution 18: 479-487.

Kumar, S., Tamura, K. \& Nei, M. 2004: MEGA3: Integrated software for Molecular Evolutionary Genetics Analysis and sequence alignment. - Briefings in Bioinformatics 5: 150-163.

McAlpine, J. F. 1981: Morphology and terminology - 
adults. - In: McAlpine, J. F., Peterson, B. V., Shewell G. E., Teskey, H. J., Vockeroth J. R., \& Wood, D. M. (eds.), Manual of Nearctic Diptera. Volume 1. Research Branch Agriculture Canada Monograph 27: 9 63. Agriculture Canada, Ottawa.

McAlpine, J. F. 1989: Phylogeny and Classification of the Muscomorpha. - In: McAlpine, J. F. \& Wood, D. M. (eds.), Manual of Nearctic Diptera. Volume 3. Research Branch Agriculture Canada Monograph 32: 1397-1518. Agriculture Canada, Ottawa.

Mesnil, L. P. 1966: Larvaevorinae (Tachininae). — In: Lindner, E. (ed.), Die Fliegen der palaearktischen Region 64g: 881-928. Stuttgart.

Muráriková, N., Vaňhara, J., Tóthová, A., Malenovský, I. \& Havel, J.: Polyphasic approach applying Artificial Neural Networks, molecular analysis and postabdomen morphology on West Palaearctic Tachina spp. (Diptera). - Systematic Entomology (In press).

Nirmala, X., Hypša, V. \& Žurovec, M. 2001: Molecular phylogeny of Calyptratae (Diptera, Brachycera): the evolution of $18 \mathrm{~S}$ and $16 \mathrm{~S}$ ribosomal rDNAs in higher dipterans and their use in phylogenetic inference. Insect Molecular Biology 10: 475-485.

Nixon K. C., 2002: Winclada, version 1.00.08. Published by the author, Ithaca, NY. [www document]. URL http://www.cladistic.com. (Site visited on March 2008)

Nylander, J. A. A. 2004: MrModeltest v2.2. - Evolutionary Biology Centre, Uppsala University. Program distributed by the author.

O'Hara, J. E. 2006: World genera of the Tachinidae (Diptera) and their regional occurrence. Version 3.0. [www document]. URL http://www.nadsdiptera.org/Tach/Genera/Gentach.ver3.pdf. (Site visited on April 2008)

O'Hara, J.E., Shima, H. and Zhang, C. 2009: Annotated Catalogue of the Tachinidae (Insecta Diptera) of China. - Zootaxa 2190: 1-236.

O'Hara, J. E. \& Wood, D. M. 2004: Checklist of the Tachinidae (Diptera) of America North of Mexico.

[www document]. URL http://www.nadsdiptera.org/Tach/Cklist/cathom.htm. (Site visited on June 2008)

Page, R. D. 1996: TreeView: an application to display phylogenetic trees on personal computers. - Computer Applied Bioscience 12: 357-358.

Pape, T. 1992: Phylogeny of the Tachinidae family-group (Diptera: Calyptrata). — Tijdschrift voor Entomologie 135: 43-86.

Sinclair, B. J. 2000: Morphology and terminology of Diptera male terminalia. - In: Papp, L. \& Darvas, B. (eds.), Contributions to a Manual of palaearetic Diptera. Volume 1: 53-74. Science Herald, Budapest.

Smith, M. A., Woodley, N. E., Janzen, D. H., Hallwachs, W. \& Hebert, P. D. N. 2006: DNA barcodes reveal cryptic host-specificity within the presumed polyphagous members of a genus of parasitoid flies (Diptera: Tachinidae). - Proceedings of the National Academy of Sciences of the U.S.A. 103: 3657-3662.

Smith, M. A., Wood, D., Janzen, D. H., Hallwachs, W. \&
Hebert, P. D. N. 2007: DNA barcodes affirm that 16 species of apparently generalist tropical parasitoid flies (Diptera, Tachinidae) are not all generalist. - Proceedings of the National Academy of Sciences of the U.S.A. 104: 4967-4972.

Stireman, J. O. 2002: Phylogenetic relationships of tachinid flies in subfamily Exoristinae (Tachinidae: Diptera) based on 28S rDNA and elongation factor- $1 \alpha$. Systematic Entomology 27: 409-435.

Stireman J. O., 2005: Phylogenetic reconstruction of Exoristinae using molecular data: a Bayesian re-analysis. - In: O'Hara J. (ed.), The Tachinid Times 18. Newsletter. Agriculture Canada, Ottawa. [also as www document]. URL http://www.nadsdiptera.org/Tach/ TTimes/TT18.pdf. (Site visited on September 2008).

Swofford, D. L. 2002: PAUP*. Phylogenetic Analysis Using Parsimony (*and other methods). Version 4.0 beta 10 win. - Sinauer Associates, Sunderland, MA. [CD-ROM].

Tachi, T. \& Shima, H. 2005: Revision of the subgenus Ceranthia Robineau-Desvoidy of genus Siphona Meigen of Japan (Diptera: Tachinidae). - Entomological Science 8: 189-200.

Tachi, T. \& Shima, H. 2006a: Systematic study of the genus Phorinia Robineau-Desvoidy of Palaearctic, Oriental and Oceanian regions (Diptera: Tachinidae). Invertebrate Systematics 20: 255-287.

Tachi, T \& Shima, H. 2006b: Review of genera Entomophaga and Proceromyia (Diptera: Tachinidae). - Annals of the Entomological Society of America 99: 4157.

Tóthová, A., Knoz, J., Sonnek, R., Bryja, J. \& Vaňhara, J. 2008: Taxonomic problems in the subgenus Meloehelea Wirth of the genus Atrichopogon Kieffer (Diptera: Ceratopogonidae) inferred from both morphological and molecular characters. - Entomologica Fennica 19: $1-12$.

Tschorsnig, H.-P. 1985: Taxonomie forstlich wichtiger Parasiten: Untersuchungen zur Struktur des männlichen Postabdomens der Raupenfliegen (Diptera, Tachinidae). - Stuttgarter Beiträge zur Naturkunde, Serie A (Biologie), 383: 137 pp.

Tschorsnig, H.-P., Richter, V. A., Cerretti, P., Zeegers, T., Bergström, C., Vanhara, J., Van de Weyer, G., Bystrowski, C., Raper, C., Ziegler, J., \& Hubenov, Z. 2004: Tachinidae. - In: Pape T. (ed.), Fauna Europaea, version 1.1 [www document], http://www.faunaeur.org (Site visited on May 2008).

Tschorsnig, H.-P. \& Herting, B. 1994: Die Raupenfliegen (Diptera: Tachinidae) Mitteleuropas: Bestimmungstabellen und Angaben zur Verbreitung und Ökologie der einzelnen Arten. - Stuttgarter Beiträge zur Naturkunde, Serie A (Biologie) 506. 170 pp. - English translation by R. Rayner \& C. Raper, authorized by H.-P. Tschorsnig. [www document]. URL http://tachinidae.org.uk/site/downloads.php. (Site visited on September 2005)

Tschorsnig, H.-P. \& Richter, V. A. 1998: 3.54. Family Tachinidae. - In: Papp, L. \& Darvas, B. (eds.), Contributions to a Manual of Palaearctic Diptera (with speci- 
al reference to flies of economic importance). Higher Brachycera. Volume 3: 691-827. Science Herald, Budapest.

Tschorsnig, H.-P., Ziegler, J. \& Herting, B. 2003: Tachinid flies (Diptera: Tachinidae) from the Hautes-Alpes, France. - Stuttgarter Beiträge zur Naturkunde, Serie A (Biologie) 656. 62 pp.

Vaňhara J., Muráriková, N., Malenovský, I. \& Havel, J. 2007: Artificial neural networks for fly identification: A case study from the genera Tachina and Ectophasia (Diptera, Tachinidae). - Biologia Bratislava 62: $462-469$.

Verbeke, J. 1962: Contribution ŕ l'étude des Tachinidae africains (Diptera); Description et valeur taxonomique des Genitalia mâles; 2. Imitomyiini, Palpostomatini et Ethillini nouveaux ou peu connus. - Resultats Scientifiques, Exploration Hydrobiologique des Lacs Kivu, Édouard et Albert (1952-1954). Volume 3: 77-187+ 25 plts. Bruxelles.

Verbeke J. 1963: The structure of the male genitalia in Tachinidae (Diptera) and their taxonomic value. - Stutt- garter Beiträge zur Naturkunde, Serie A, (Biologie) $114.8 \mathrm{pp}$.

Vossbrinck, C. R. \& Friedman, S. 1989: A 28S ribosomal RNA phylogeny of certain cyclorrhaphous Diptera based upon a hypervariable region. - Systematic Entomology 14: 417-431.

Wood, D. M. 1987: Tachinidae. — In: McAlpine, J. F., Peterson, B. V., Shewell, G. E., Teskey, H. J., Vockeroth, J. R. \& Wood, D. M. (eds.), Manual of Nearctic Diptera. Volume 2. Research Branch Agriculture Canada Monograph No. 28: 1193-1269. Agriculture Canada, Ottawa.

Zimin, L. S. \& Kolomietz, N. G. 1984: (Parasitic Diptera of the USSR fauna (Diptera, Tachinidae). The Key.) — Nauka, Novosibirsk. 233 pp. [In Russian.]

Zimin, L. S., Zinověva, K. B. \& Stackelberg, A. A. 1970: Tachinidae (Larvaevoridae). — In: Stackelberg, A. A. \& Nartshuk, E. P. (eds.), (Diptera, Siphonaptera. Insect key of the European part of Soviet Union). Vol. 5 (1-2): 678-798. Nauka Leningrad. [In Russian.] 